\title{
RAMONISMOS CONTEMPORÁNEOS: LA GREGUERÍA EN LAS OBRAS DE JUAN MANUEL DE PRADA, JUAN BONILLA Y RAY LORIGA
}

\author{
Simone Cattaneo \\ Università degli Studi de Milán
}

\begin{abstract}
RESUMEN: El presente ensayo analiza la presencia de la greguería en las obras de tres autores que empezaron a publicar en los años 90 del siglo XX, cuando estaba en alza una novela marcada por un crudo realismo juvenil, entre las aristas del cual afloró un sorprendente redescubrimiento de Ramón Gómez de la Serna, cuya influencia es notoria en Juan Manuel de Prada y Juan Bonilla, mientras que se refleja de forma sesgada en Ray Loriga, ya que su pluma, más escueta, pule la greguería a través de la canción y del magisterio de Marguerite Duras. En el caso de los primeros se asiste a una contraposición cáustica o humorística con respecto al realismo literario dominante, en cambio para Loriga se trata de una visión personal, debida tanto a una inclinación anímica como a una melancólica rebelión contra la sociedad.
\end{abstract}

PALABRAS CLAVE: Juan Manuel de Prada, Juan Bonilla, Ray Loriga, Ramón Gómez de la Serna, greguerías, narrativa española del siglo XX.

\section{CONTEMPORARY "RAMONISMOS": THE GREGUERÍA IN JUAN MANUEL DE PRADA'S, JUAN BONILLA'S AND RAY LORIGA'S WORKS}

\begin{abstract}
This essay analyzes the presence of the greguería in the works of three authors that started to publish in the '90s, a period in which novels based on a harsh juvenile realism were very widespread. However, in that decade, Ramón Gómez de la Serna surprisingly was taken as a model by Juan Manuel de Prada and Juan Bonilla, while his influence in the texts of Ray Loriga is subtler and not so obvious, because his less exuberant writing tends to combine the greguería's perspicacity with the laconicism of song lyrics and the prose of Marguerite Duras. For the first two writers it was a way to rebel against the dominant realism through a caustic or a witty humour, whilst in Loriga that aphoristic style was determined by a personal approach due to his sensibility and his melancholic rebellion against society.
\end{abstract}

KEYWORDS: Juan Manuel de Prada, Juan Bonilla, Ray Loriga, Ramón Gómez de la Serna, greguerías, Twentieth-Century Spanish Narrative. 
Los autores objeto del presente estudio son Juan Manuel de Prada (Baracaldo, 1970), Juan Bonilla (Jerez de la Frontera, 1966) y Ray Loriga (Madrid, 1967), tres nombres que en la década de los 90, a causa de un afán clasificatorio entreverado de intereses literarios y crematísticos, fueron incluidos, junto con otros escritores, en la que se dio en llamar "Generación X", un grupo heterogéneo que si bien por un lado se configuraba como expresión fidedigna del entorno socio-cultural y económico de esa época (Cattaneo 2012: 53-85), por otro mostraba las fisuras propias de cualquier método generacional (45-51). Pero en estas líneas, conscientes de las arenas movedizas que rodean el término "generación", no nos enzarzaremos en disquisiciones teóricas sobre dicho concepto, sino que, siguiendo la estela de Ramón y rozando la hibridación entre escritura y música, nos centraremos en el manejo de la lengua por parte de Prada, Bonilla y Loriga porque en sus textos, a pesar de que los tres tengan trayectorias literarias y sensibilidades muy diferentes, aflora de forma directa o indirecta la sombra del grafómano madrileño.

Juan Manuel de Prada, una rara avis en el contexto literario de los $90^{1}$ marcado por una estética volcada en una prosa escueta y brutal -deudora de cierta literatura norteamericana recibida en España a través de un filtro equivocado que, al leer de forma distorsionada el fenómeno del Dirty Realism estadounidense, había favorecido la difusión de la etiqueta "realismo sucio" (Santana 2007: 33-56)-, es un novelista que desde sus comienzos había reivindicado sus raíces españolas -reconociendo sin embargo la influencia fundamental de Proust y Borges (Montetes Mairal 1999: 284-285)-. Su forma de narrar es una lucha encarnizada entre los límites de la página y su fertilidad creadora (Cuenca 1996: 9), puesto que obedece a una distorsión literaria congénita de la realidad: "Creo que soy un escritor impetuoso, barroquizante, pesimista, que concibe la realidad como un aquelarre y percibe el mundo sobre todo a través de los sentidos, como mis dilectos Ramón y Felisberto Hernández" (Montetes Mairal 1999: 291-292).

Su deuda con Ramón se manifiesta a partir de su primer libro, Coños (1995), que surge al amparo de un epígrafe ramoniano y constituye un homenaje socarrón a Senos (1917)² (Cuenca 1996: 9; Acín 2003: 14; García Jambrina 2005: 13), ya que el objeto de la sorna pradiana es otra parte de la anatomía femenina, convertida

1. "Coños [...] era divertido y libertino, audaz y desbordante, blasfemo y heterodoxo. Nacía a contra corriente. No era literatura que entonces estaba de moda, sobre todo porque no era literatura rápida para un consumo fácil" (García 2003: 158).

2. "Yo acababa de leer Senos de Gómez de la Serna, y [a Luis García Jambrina] le propuse dar una vuelta de tuerca al asunto y escribir sobre coños" (Bueres 1996: 33). 
en un pretexto para ensartar greguerías bajo el magisterio ramoniano (Prada 2008c) ${ }^{3}$, al dictado de una mirada hiperestésica (Luna 1998: 121) y de unas "asociaciones insólitas de las palabras [que] evoquen el fulgor de las imágenes” (Montetes Mairal 1999: 283). Es precisamente esa voluntad de trabar correspondencias dispares lo que le acerca a Gómez de la Serna, dado que en la obra de éste "la palabra se pliega a las necesidades del absurdo y la arbitrariedad y se absurdiza ella misma (mediante sus uniones libres y gitanas -que resultan del azar-)" (Serrano Vázquez 1991: 51), pero en el caso de Prada es imprescindible subrayar su pasión por el "fulgor de las imágenes", algo que también Gullón (2003: 177) ha captado, porque esta idiosincrasia limita los ámbitos creativos de sus greguerías, las cuales se fundamentan sobre todo en la metáfora, el símil y sus variantes, excluyendo los juegos basados en la fonética y la grafía de los significantes o en la polisemia de las palabras.

Ya desde Coños se nota la afición del autor por un determinado tipo de construcciones que se mantendrán constantes a lo largo de sus libros sucesivos, en los cuales, a pesar de que se trate en su mayoría de novelas extensas, será siempre posible descubrir unos destellos que suenen a homenaje a Ramón ${ }^{4}$, orquestados por medio de una escritura plástica que, desde una perspectiva extravagante o esteticista, busca amalgamar la exactitud de la poesía (García 2003: 160) con el ímpetu de su prosa ${ }^{5}$,

3. Las similitudes entre Senos de Gómez de la Serna y Coños de Prada merecerían un largo ensayo aparte, pero aquí nos limitaremos a ofrecer una rápida comparación entre los índices de los dos libros. Si en las páginas de Ramón era posible toparse con "Los senos de la nadadora" (Gómez de la Serna 1998: 554), "Los senos de las monjas" (567), "Los senos de la domadora" (567), "Senos de querubina" (568), "Senos de viuda" (592), "Senos de sirena" (598), "Los senos de la enfermedad grave" (601), "Senos de circo" (606), "Las niñas" (608), "Las muertas" (611), "Las negras" (620), "Los senos de las muñecas de cera" (629), "Los senos de las estatuas" (633), "Senos de cubanas" (654), en aquéllas del escritor de Baracaldo no sorprenderá descubrir "El coño de la bañista" (Prada 2005: 141), "El coño de la monja budista" (201), "La domadora de leones" (185), "El coño de los ángeles" (227), "El coño de las viudas" (181), "Los coños de Melusina" -Melusina es una sirena- (128), "El coño de la tuberculosa" (161), "El coño de la funámbula" (145), "El coño de las niñas" (137), "Coños en la morgue" (219), "El coño de las batutsis" (63), "El coño de las muñecas" (193), “Arqueología del coño" (47), "El coño de las cubanas" (121). En todos estos textos además, como se verá en los ejemplos brindados en el artículo, Prada recurre frecuentemente a la animalización, la cosificación y la personificación, distorsiones ya aplicadas por Gómez de la Serna en Senos (Cabañas Alamán 2008: 217-218).

4. A este propósito es interesante destacar la lectura que Cabañas Alamán (2008: 209-232) hace de La vida invisible, como si la considerara una reescritura de Senos.

5. "Mi lenguaje es poético. Procuro abordar la prosa con las armas de la poesía, no recurrir a la frase hecha" (Bueres 1996: 37). La de no caer en las trampas de la "frase hecha" fue una preocupación que aquejó también a Ramón (Serrano Vázquez 1991: 51). García Yebra (1994: 36) luego, al escribir sobre Gómez de la Serna, enfatiza su manejo de la poesía: "Ramón lleva a la prosa los elementos de la poesía tradicional". 
empleando a menudo una adjetivación rebosante e inusual ${ }^{6}$. De ahí que tanto en los cuentos de El silencio del patinador (1995) como en sus narraciones posteriores - Las máscaras del héroe (1996), La tempestad (1997), Las esquinas del aire (2000), La vida invisible (2003) y El séptimo velo (2007)-, la greguería siga siendo una presencia constante, aunque vea disminuida su frecuencia y, adoptando el término utilizado por López Molina (2008: 117-144) en su análisis de la obra de Gómez de la Serna, acentúe su carácter "intratextual", "constituy[endo] un elemento inscrito en otro más amplio y complejo con el que se entrelaza pero con el que no se confunde" (122). Como muestra de lo afirmado, aportamos un conjunto de greguerías pradianas que ordenaremos según las categorías elaboradas por Serrano Vázquez (1991) en su estudio El humor en las greguerías de Ramón. Recursos lingüísticos y que, cuando sea preciso, pondremos en relación con otras escritas por el fundador de las tertulias del café Pombo. Si nos atenemos a la clasificación gramatical de Serrano Vázquez a propósito de las metáforas empleadas por Gómez de la Serna, veremos que Prada también utiliza a menudo la "metáfora atributiva: (A es B)" (Serrano Vázquez 1991: 209; Gómez Yebra 1994: 44): "El coño de las estatuas griegas es un pellizco de mármol"7 (Prada 2005: 48); "El coño de las recién casadas es el corazón que aún le queda a la cebolla una vez apartadas todas las capas de blancura" (118) ; "La guerra [...] era un hospital inmenso con poca luz y demasiado ruido" (Prada 1997: 148); "El plagiario es un mudo que habla con el eco de otros" (Prada 2008a: 427); "el dolor [...] es un azogue siempre insatisfecho que lanza mordiscos a ciegas" (Prada 2007: 462); "El miedo era un perro meando en cada esquina" (Prada 2008b: 537); etc. Otro recurso ramoniano es la "metáfora aposicional (A:B o B:A); (A, B o B, A)" (Serrano Vázquez 1991: 210), señalada también por Gómez Yebra (1994: 44) en la variante " $A=b_{1}, b_{2}, b_{3}$ ": "Las mujeres batutsis, lingotes negros en mitad de la selva" (Prada 2005: 65); "El coño de las

6. "la exquisitez rigurosísima con la que [Prada] construye sus frases alcanza culmen en la elección de los adjetivos" (Castillo Gallego 1999: 160). También Sabugo Abril (1988: 11) al referirse a Ramón pone de relieve su adjetivación: "La revolución estética comienza por el vocabulario [...]. En vez de la esencialidad del nombre, la fragmentación de la realidad, el mosaico de adjetivos que re-componen caóticamente (como las mismas greguerías) la unidad del texto (del universo)".

7. A pesar de no tener una misma estructura gramatical, la siguiente greguería de Gómez de la Serna guarda cierto parecido con la pradiana y podría haber servido de inspiración para el escritor de Baracaldo, puesto que en ambas se usa el tema de la estatua para referirse a la perfección de la anatomía femenina a través de la tersura del mármol: "El milagro del mármol se revela cuando aparecen los senos de la estatua" (Gómez de la Serna 1962: 126). A ésta podría añadirse otra: "Las Venus marmóreas de los museos presentan manchas de pellizcos" (257).

8. Ramón, en cambio, se había fijado en el ajo y en su traje de novia: "Los ajos están vestidos de novia" (Gómez de la Serna 1962: 1298). 
filipinas, ese bibelot de porcelana rosa" (174)9; "En sus escotes, afloraba la ofrenda de los senos, esa luna creciente que pugnaba por hacerse llena" (Prada 1997: 58); "la Pedrera de Gaudí, aquel oleaje de piedra lunar" (Prada 2008b: 363); etc. No faltan luego, a causa de las construcciones sintácticas usadas por el autor-frecuentemente basadas en sintagmas preposicionales pospuestos a nombres o adjetivos (Cattaneo 2012: 163)-, ejemplos de "metáfora[s] de complemento preposicional (B de A) o (A de B)" (Serrano Vázquez 1991: 210): "un coño profundo, moreno de generaciones y soles lejanos" (Prada 2005: 69); "La luna se posaba en los jardines con una violencia de vidrios rotos" (Prada 1997: 88); "La ebonita del disco tenía un brillo de charol o pantera adolescente" (Prada 2008a: 404); etc. Aunque quizás la figura retórica que constituye la piedra angular de la greguería pradiana sea el símil, tanto a través de la construcción "A como B" como de "A parece B" (Serrano Vázquez 1991: 215): “Las familias gitanas llegan en sus carromatos que parecen embarcaciones a punto de naufragar o bazares nómadas" (Prada 2005: 67); "sus lágrimas parecen joyas de una bisutería lenta" (69); "Hablaba sin pausas, como una pastilla efervescente que se disuelve en agua y desborda el vaso" (Prada 1997: 89-90) ${ }^{10}$; "Las perneras del pantalón, muy holgadas, le caían sobre las alpargatas, como un acordeón sin música” (Prada 2000: 46) 11; "sus anuncios luminosos que se encendían y apagaban como si su caligrafía se la dictase Dios" (418) ${ }^{12}$; "ojos transparentes y acuosos, como hielos que se derriten porque lloran de frío" (Prada 2007: 140) 13; "reconoció como golondrinas aquellas criaturas aladas que surcaban el aire como saetas disparadas por la ballesta de Dios" (Prada 2008b: $80)^{14}$; etc. Sin embargo, son muy raras las greguerías que Gómez Yebra ejemplifica por medio del esquema "A" que coincidiría con la "metáfora pura o de sustitución

9. Aquí hay quizás un eco de los "senos japoneses” de Gómez de la Serna (1998: 688), donde, como en Prada, la materia de la que están hechos se pone en relación con la tradición artesanal del país evocado: "Los senos japoneses son senos menudos, senos de malaquita a veces. Otras veces de jade".

10. Gómez de la Serna (1962: 726) había aprovechado la misma estructura y un símil parecido: "Hablaba a borbotones, como cuando se desagua el baño".

11. En esta greguería hay una inversión con respecto a la personificación llevada a cabo por Ramón: "El acordeón tenía los pantalones rotos" (Gómez de la Serna 1962: 712).

12. El tema de los letreros luminosos es frecuente en las greguerías ramonianas: "Hay unos anuncios luminosos que son sanguijuelas de nuestra atención" (Gómez de la Serna 1962: 88); "Los anuncios que se encienden letra a letra nos convierten en niños que deletrean" (382); etc.

13. Esta es casi una cita literal de Gómez de la Serna (1962: 276): "El hielo se derrite porque llora de frío".

14. Sin duda en esta frase laten reminiscencias ramonianas: "La golondrina llega de tan lejos porque es flecha y arco al mismo tiempo" (Gómez de la Serna 1962: 307); "La golondrina es una flecha mística en busca de un corazón" (314). 
simple" de Serrano Vázquez (1991: 210), o sea una metáfora -atributiva o aposicional- en la que se ha omitido uno de los dos términos, o un símil que no se apoya en una construcción comparativa explícita (Gómez Yebra 1994: 45): "el atlas desdoblado de sus nalgas" (Prada 2005: 71-72); "una leche grumosa de nata que caía en el plato, formando lunas prisioneras" (210); "La noche tenía una limpieza de puñal húmedo e incruento" (Prada 2007: 262); “Amarilleaban las hojas de los árboles, se incendiaban los tonos rojizos, en una hoguera hermosamente agónica, hermosamente inútil que trataba de ahuyentar el invierno" (Prada 2008a: 419); etc.

Si del ámbito gramatical nos desplazamos al semántico, es posible observar ulteriores afinidades entre Gómez de la Serna y Prada, puesto que uno de los procedimientos más explotados por el escritor de Baracaldo es el de la personificación. Su mirada propende a asignar a las cosas acciones humanas, con un claro guiño al "animismo irónico" (Serrano Vázquez 1991: 180) de Ramón, empleando, además, en la mayoría de los casos, al igual que el inventor de las greguerías (183), el verbo como elemento de desestabilización semántica. En la frase "El coño de las solteronas [...] mantiene siempre encendida una llama votiva y ruega a Dios por el regreso del hombre" (Prada 2005: 100), son la expresión "mantener encendida" y el verbo "rogar" los elementos que ponen en relación un órgano que no puede expresar sentimientos con unas manifestaciones humanas de esperanza y fe; otros ejemplos serían: "llevaba la Presidenta un collar de perlas que sonreía con su sonrisa de dientes gordos" (Prada 1997: 138) ${ }^{15}$; "El acero [del sable] le hacía cosquillas al aire con su sonrisa corba [...] junto a los paraguas que reprimían bostezos" (Prada 2007: 238); "el bostezo cóncavo de los túneles" (595) $)^{16}$; etc. Una alternativa a la "humanización" de objetos inanimados, como ya había descubierto Gómez de la Serna, es su transformación en animales ${ }^{17}$ : "El coño de Amanda era un felino por-

15. Aquí Prada, a través de la humanización, reelabora una greguería ramoniana: "Collar de perlas: dentadura para las gargantas" (Gómez de la Serna 1962: 100).

16. En esta serie de greguerías pradianas se insiste en el "bostezar" de las cosas, una característica "humana" de los objetos detectada por Gómez de la Serna (1962): "Cuando el armario está abierto, toda la casa bosteza" (502); "En la gruta bosteza la montaña" (541); "Los arcos tienen el bostezo de los siglos" (1311); etc. Siempre en estas líneas, además, se atribuye al acero la posibilidad de hacer cosquillas al aire y a los paraguas la de portarse como seres humanos; se trata de personificaciones ya esbozadas por Ramón: "Las espigas hacen cosquillas al viento" (147); "Los paraguas son viudas que están de luto por las sombrillas desaparecidas" (534).

17. "Hablamos de animalización cuando un elemento marcado por el clasema 'inanimado' o por el clasema 'animado', subclasema 'humano', recibe, por adición traslaticia y como resultado de una combinación anómala, el subclasema 'animal' del lexema con el que se combina” (Serrano Vázquez 1991: 207-208). 
tátil que parecía querer salirse de la jaula de sus labios" (Prada 2005: 188); "Me aflojé la corbata de pajarita, absurda como un murciélago a plena luz del día" (Prada 2008a: 416); "los senos como animales núbiles y perplejos" (Prada 2006: 154); "Las manos de Tabares parecían dos sapos mellizos que han decidido aparearse, infringiendo el tabú del incesto" (Prada 2000: 158) ${ }^{18}$; "el crepúsculo estrellándose como un vencejo ciego" (Prada 2007: 120); etc. Al lado de la "animalización" hay también una tendencia a la "vegetalización" que funciona al revés con respecto a la personificación de plantas o elementos de la naturaleza teorizada por Serrano Vázquez (1991: 181), puesto que Prada atribuye propiedades vegetales a cosas que no pertenecen a dicho ámbito: "Gertrudis tiene [...] un coño que como la manigua, puede llegar a oprimir con su maleza al viajero inadvertido" (Prada 2005: 122)19; "el continente ancho de sus muslos, esa artesanía de carne como fruta o fruta como carne" (146); "Tenía el rostro entorpecido de barba, como un bosque calcinado" (Prada 2008a: 116); etc. Una variante más radical de esta técnica es la "reificación", una distorsión ramoniana (García Yebra 1994: 46) que convierte lo humano en algo inanimado y que comulga con la visión desmitificadora de Gómez de la Serna, ya que "Humanización y cosificación son dos facetas de un mismo fenómeno cuyo fundamento es la igualación prosopopéyica de personas y cosas" (Serrano Vázquez 1991: 83). Prada también parece fascinado por esta posibilidad: "El coño de las violonchelistas [...] quizás sea un metrónomo que marque el compás con su clítoris" (Prada 2005: 31); "unas rodillas como monedas de pan" (72) ${ }^{20}$; "Colombine [...] al andar, parecía un barco ebrio de marejadas" (Prada 2008a: 59); "El vientre como una guitarra muda” (Prada 2006: 154); etc.

En la confrontación entre la maestría de Gómez de la Serna y el estro pradiano juzgamos además oportuno citar otros fragmentos -donde se combinan entre sí la metáfora atributiva, la metáfora aposicional, el símil y otros recursos semánticosen los que afloran alambicadas imágenes a mitad de camino entre la esbeltez ramoniana y una escritura barroca que a veces, por un exceso de funambulismo, da lugar a greguerías hipertróficas que parecen remitir a las creaciones primerizas de

18. Prada aprovecha una metáfora ramoniana, volviéndola del revés, para convertir las manos en sapos allá donde Ramón había transformado los cangrejos en manos: "Los cangrejos son manos de pianistas torpes tocando barcarolas" (Gómez de la Serna 1962: 352).

19. Esta transformación de una parte del cuerpo en un elemento vegetal parece un guiño directo a Gómez de la Serna (1998: 685-686): "Entre los [senos] de la América del Sur y Cuba los hay de un gran interés frutal, los hay como piñas maduras de gusto distinto y dulcísimo; los hay como hechos del tuétano de la caña de azúcar".

20. Gómez de la Serna (1962: 1288) había transformado las rodillas en naranjas: "Tenía por rodillas dos naranjas". 
Ramón, más profusas y menos quintaesenciadas (García Yebra 1994: 49). Entre estos retazos poéticos destaca el siguiente, que gira alrededor de la personificación y está plagado de ecos ramonianos ${ }^{21}$ :

La violonchelista [...] agarra [el instrumento] del cuello, le pinza las cuerdas vocales y le frota el pecho con el arco, hasta herirlo en el corazón y hacerle llorar un si bemol. [...] En el intermedio del concierto, vemos a la violonchelista ajustándole las clavijas a ese hombre de madera, como la mujer retuerce las orejas al amante que no responde en la cama (Prada 2005: 30-31).

Otros ejemplos que podrían inscribirse en dicho grupo serían: "En la calle de Montera se amontonaban las putas, con su aire de cariátides deshauciadas a las que un arquitecto poco respetuoso de los cánones clásicos hubiese colocado precisamente ahí para soportar el peso de las fachadas" (Prada 2007: 507)²2, "El crepúsculo mugía como un toro que se desangra [...]. Los vencejos [...] en el cielo trazaban, como arquitectos improvisados, estelas que eran bóvedas y arbotantes tejidos en el aire, ábsides y cúpulas de elegancia ojival, catedrales de algarabía" (Prada 2008b: 99)23; etc. En contraposición a éstas es posible hallar alguna que otra reflexión lapidaria con un deje más aforístico, pero en general se trata de unas excepciones: "La locura nos asusta porque nos habla de esa parte de nosotros que desea morir" (Prada 2007: 147) ${ }^{24}$; "Siempre es otoño en los cementerios" (Prada

21. De hecho, hay algunas greguerías protagonizadas por violinistas o violonchelistas que recurren a la personificación: "Como la cabeza del violoncelista está cerca de la rizada cabeza del violoncelo, todo sucede según las palabras que se digan al oído” (Gómez de la Serna 1962: 1261); “Al afinar el violín se le tira de las orejas" (1283); etc.

22. Esta podría ser una reelaboración más despiadada de la greguería "Los esquineros son un cuerpo especial como en el ejército existe el de los pontoneros o el de ametralladoras. Hay los que están frente a la esquina, en la línea de la acera y los que están pegados al mismo esquinazo como cariátides del ángulo" (Gómez de la Serna 1962: 1433).

23. En esta ocasión Prada fusiona varias greguerías ramonianas, usando la imagen de los toros, o de los bueyes -relacionados normalmente por Gómez de la Serna con las tormentas-, para "animalizar" una parte del día y, de la misma manera, retoma las golondrinas ramonianas -aquí convertidas en vencejos- en cuanto seres dotados de características humanas que trazan en el aire dibujos misteriosos: "El toro de la tormenta desbanda al gentío" (Gómez de la Serna 1962: 228); "Se oye el cerrojo del primer trueno y se desencadena la tormenta como toro que sale del toril" (1053-1054); "Muchas golondrinas en el aire: escritura china" (124); "Las golondrinas llenan de firmas el pergamino del cielo en homenaje del buen tiempo" (127); "Las golondrinas bordan el cañamazo de la tarde" (299); etc.

24. En este caso el tono de la frase roza la solemnidad del aforismo porque hay oculta en ella una suerte de enseñanza moral, un elemento que, en general, no se encuentra en la greguería, la cual obedece a una finalidad más lúdica y aboga por una menor afectación (García Yebra 1994: 32-33) en su tentativa de comprender y representar el universo a través de la metáfora y no del pensamiento (Sabugo Abril 1988: 18). 
2008b: 152); etc. La escasez de estas últimas parece un aspecto capaz de estrechar todavía más los lazos entre Prada y Ramón, dado que si confrontamos la greguería con el aforismo, es evidente que en ésta predomina "la distensión, el buen humor, la gracilidad, el ingenio, la agilidad mental y el lirismo" (García Yebra 1994: 33) y tanto Serrano Vázquez (1991: 21) como Ródenas de Moya (2008: 28) subrayan que un ingrediente casi imprescindible en su elaboración es el humor ${ }^{25}$. Entonces será precisamente éste el concepto que pueda ofrecernos el diestro para deslindar la relación que subsiste entre la labor ramoniana y la pradiana, dos visiones del mundo que sólo en apariencia coinciden.

Serrano Vázquez (1991: 221-222), muy acertadamente, señala que el humor para Ramón era una actitud vital, un disfraz para evadir de un contexto que consideraba hostil, una manera de humanizar las cosas y, finalmente, un producto de las vanguardias que le había servido para llevar a cabo una renovación formal dirigida contra la novela realista, combatiéndola a través de la atomización de la escritura y aprovechando la metáfora y la imagen como recursos estilísticos subversivos (Ródenas de Moya 2008: 30). Esta revolución se repercutiría en dos ámbitos: el existencial y el estético. Por un lado se trataba de encontrar una forma más llevadera de soportar la condición del ser humano (Serrano Vázquez 1991: 40); por otro, dicho remedio no podía no aplicarse a la literatura que, para Ramón, iba ligada indisolublemente a su existencia, pero en ambos casos la palabra clave que ocupa el centro de las murallas defensivas erguidas a su alrededor podría ser "levedad"26, un vocablo que resume en sí esa actitud definida por Gaspar Gómez de la Serna (1963: 116) como una vía "incongruente y jovial, en la que puede ejercerse un mester de salvación de las cosas haciendo aparecer a éstas subsumidas en una especie de tercera dimensión de alegre realidad hipotética y sorpresiva" y que persistirá incluso en su postrera etapa creadora, cuando el entusiasmo juvenil deje paso a "cierta angustia existencial que busca en la salvación humorista de la realidad también la salvación de sí mismo" (119).

25. Sin duda el humor, ya a partir de la famosísima definición que dio Ramón de la greguería _"Humorismo+metáfora=greguería" (Gómez de la Serna 1962: 35)-, es un componente esencial de la misma; sin embargo, en contadas ocasiones, es posible encontrar algunas greguerías de tono más sombrío: "Convertido en brasa el carbón, se acuerda de todo, hasta de cuando era árbol verde en un mundo lleno de esperanzas" (141); "Lo peor de las ruinas es que ocultan el alacrán" (154); "Los ojos de los muertos miran las nubes que no volverán" (476); etc.

26. "La nueva literatura es evasión, alegría pura entre las palabras y los conceptos más diversos [...], desvariar con gracia" (Gómez de la Serna 1962: 35). 
La trayectoria de Prada, en sus comienzos, también se configuró como una evasión y una reacción al entorno literario, donde primaba una prosa realista, desprovista de oropeles, de la que cabía rehuir a través de una actitud esteticista cimentada en la creación literaria (Núñez 1998: 35). Se trataba de una postura cercana a la de las vanguardias de comienzos del siglo XX y que, por ende, parecería brotar de un contexto afín al de Ramón, sin embargo Prada acentúa la visión decadente de cierto tipo de bohemia que había hecho mella en su imaginario ${ }^{27}$, cargándola de tintes tremendistas o esperpénticos provenientes tanto de la tradición literaria española ${ }^{28}$ como de cierto cine pulp al que era aficionado (Luna 1998: 121). El resultado de tal mezcla es una escritura barroca, en ocasiones amazacotada -en estos últimos años, de hecho, ha desembocado en un remedo de los folletines decimonónicos (Cattaneo 2012: 201-210)-, y un humorismo que no se propone emancipar al hombre ni a las cosas, sino que funciona como un espejo deformante cuyos reflejos despiadados se subliman, a la manera de Valle-Inclán ${ }^{29}$, gracias al cincel del estilo. De ahí que el humor en Prada se asocie a "la insinuación procaz [...], la instantánea macabra, [...], la erudición desmitificadora" (Castillo Gallego 1999: 156); "[la] ironía, [la] crítica e, incluso, la crueldad" (Acín 2003: 24), cualidades que lo alejan de la burlona y melancólica alegría ramoniana y desvían su pluma hacia una torsión expresionista incline al detalle siniestro o hacia una prosa poética que, a pesar de su calidad literaria, se reduce a menudo a puro ornato en un proyecto narrativo que, al rescatar los compases del feuilleton clásico, no puede considerarse innovador y corre el riesgo de engrosar las filas de cierta narrativa popular. Representativas del expresionismo del autor serían, además de los camafeos sarcásticos que afloran constantemente en sus páginas ${ }^{30}$,

27. Prada ha escrito profusamente sobre autores denostados y olvidados pertenecientes a la bohemia mugrienta de las primeras décadas del siglo XX: entre sus textos más significativos destacan Armando Buscarini o el arte de pasar hambre (1996) y Desgarrados y excéntricos (2001), a los que hay que añadir las novelas Las máscaras del héroe y Las esquinas del aire.

28. "Prosa nacida en la vanguardia y templada en el clasicismo, tan acribillada de metáforas y de rasgos de ingenio que se diría que uno está leyendo al mismísimo Quevedo, o a Valle-Inclán, o a Cela, o a Umbral" (Cuenca 1996: 9).

29. "Prada, al igual que Valle-Inclán, es un reinventor del lenguaje. Su prosa, decididamente esteticista y plástica, combina cultismos con expresiones soeces y escatológicas, y el más cuidado lenguaje modernista con rasgos esperpénticos [...]. Entre los rasgos estilísticos del lenguaje de Valle-Inclán, la crítica ha apuntado su preferencia por los contrastes, los juegos de palabras antitéticas y las enumeraciones caóticas [...] y, en general, un desajuste entre el léxico brillante utilizado y la vulgaridad del referente. Todos estos rasgos definen la obra de Prada" (Gómez 2001: 116-117).

30. Luis de la Peña (1997: 28), a propósito de Las máscaras del héroe, pone en evidencia que la "descripción despectiva por los tipos humanos, [...] al igual que en la de Cela, recurre a rasgos animaloides para el dibujo humano". Ejemplos de esta deformación se encuentran en varios pasajes de la obra pradiana: 
las siguientes greguerías: "el coño de las menopáusicas, huérfano de flores rojas, necrófago de sí mismo” (Prada 2005: 170); “El cielo de Barcelona tenía un color sucio, grisáceo con irisaciones verdeantes, como la panza de un burro muerto que se ofrece de festín a las moscas" (Prada 2008b: 394) 31; etc. A la vertiente poéticoestética pertenecerían, en cambio, estas otras: "Los coloquios amorosos están compuestos de palabras borrachas que trastabillean y caminan sinuosamente, dando rodeos para volver al lugar de partida, y así hasta el infinito, como animales amarrados a una noria que, pese a la repetición de su tarea, no muestran señales de cansancio" (Prada 2007: 54); "Noviembre descendía del cielo disfrazado de invierno, como un caballo encabritado que arrastrara consigo las aldeas nevadas de Chagall" (Prada 2008b: 166) ${ }^{32}$; etc.

Entonces es fácil intuir que por el lado del humor la escritura pradiana roza una de las opciones que el mismo Ramón había descartado, la de "la amarga vía que lleva a subrayar la gibosidad dolorida del mundo con el trazo grotesco del escarnio o del ridículo que desemboca en lo sarcástico, en el humorismo de lo que se llama un cáustico" (Gómez de la Serna 1963: 116), mientras que, por el lado de la estética, su postura barroquizante le conduce a rescatar tropos típicos de la greguería, dado que éstos le permiten ora dar una vuelta de tuerca más a su expresionismo ora adentrarse por los senderos de lo poético porque Prada, en realidad, no encuentra nuevos métodos para trabar asociaciones dispares, sino que, al recuperar la óptica ramoniana, aprovecha al pie de la letra los mecanismos explotados por su antecesor y, de esta manera, lo que la mirada de Gómez de la Serna transformaba en una "metáfora cómica" quizás se convierta en la mayoría de los casos en las

\footnotetext{
“Apareció un hombre de constitución endeble y rostro como de gárgola [...]” (Prada 2006: 136); "Era una mujeruca consumida por el insomnio [...] muy amojamada y menuda [...] Tenía un rostro bovino y al mismo tiempo rapaz, en insólita hibridación zoológica" (Prada 2000: 89); etc.

31. Por enésima vez el autor de Baracaldo rescata y adorna un símil de Gómez de la Serna (1962: 386): "Hay unas nubes largas y finas que son como costillas del cielo". También el creador de las greguerías, de vez en cuando, se adentraba en lo macabro, pero en general se trataba de excepciones que no constituían la dominante de su visión: "Son senos que dan pena porque son como dos ratas muertas, colgadas de sus pechos de niñas" (Gómez de la Serna 1998: 574); "los senos que transporta en una bandeja la pobre santa Eduvigis [...] parecen un par de ojos saltones o un par de huevos fritos, entre cuya clara, muy cuajada, se ve la mancha rojiza de una yema de huevo a medio empollar" (578); etc. Prada, en cambio, apuesta por retomar reiteradamente esta faceta ramoniana más corrosiva.

32. Una imagen poética del invierno con una estructura parecida, en la que hay una animación de dicha estación -“se echa"- y al mismo tiempo una cosificación -"el libro del invierno"-, había sido ofrecida por Gómez de la Serna (1962: 164): "El libro del invierno se echa a nuestros pies como si hubiese salido del bosque que arde en la chimenea". A ésta añadimos otra que quizás podría haberle sugerido a Prada la referencia al pintor ruso Chagall: "Los domingos de invierno tienen desolada luz rusa" (636).
} 
manos de Prada -y en las de un lector consciente del magisterio de Ramón- en una "metáfora tradicional" 33 .

En una posición cercana a la del autor de El séptimo velo es posible situar a Juan Bonilla ya que él también desde sus escarceos literarios ha pregonado su admiración por Gómez de la Serna, sobre todo a través de El pasado resuelto y Literatura mon amour, textos incluidos en El arte del yo-yo $(1996)^{34}$. El primero de ellos es el más significativo porque en él se narra la breve vida de un joven escritor, Gonzalo Serna, que ambiciona redactar un "nuevo diccionario en el que todas las definiciones fueran poéticas" (Bonilla 1996a: 234), basado en la greguería ramoniana -sobre la cual se esboza un microensayo $(234-238)^{35}$-, al ser consciente de que "Las mejores [greguerías] persiguen alumbrarnos el mundo, hacerlo más grande, más hondo, más hermoso, con una herramienta eficaz e imperecedera: el humor" (238). En estas líneas queda resumida la estética bonillana, cuyo pilar de carga será precisamente lo poético acompañado de un tono desenfadado que, junto a la ironía y al ingenio, parece connatural a su mirada (García Rodríguez 2008: 19). Este tipo de aproximación le viene a Bonilla, como a Prada, del rechazo del realismo en boga en los 90 , juzgado una corriente literaria que por su deuda con el presente histórico podría convertirse, con el transcurrir del tiempo, en mero documental sociológico despojado de cualquier aspiración artística (Bonilla 2001). Además sus reflexiones alrededor de la utilidad de la literatura, lo habían llevado muy pronto a una conclusión que encierra en sí la esencia de la actitud ramoniana -analizada anteriormente- frente a las dificultades de la existencia, puesto que para Bonilla (1996a: 288) "la literatura sirve para que la vida nos concierna menos de lo que seríamos capaces de soportar".

33. La "metáfora será poética o tradicional cuando se fundamenta en un parecido que juzgamos esencial entre sus dos miembros [y] [...] el lector puede asentir a la identificación realizada por el poeta" (Serrano Vázquez 1991: 168), mientras que será “cómica cuando el parecido entre los términos A y B, aunque existente, resulta mínimo, inesencial” (168). Hoy en día, después de la lección de Gómez de la Serna y las experimentaciones de los vanguardistas, quizás se podría hipotizar que, a estas alturas, el lector haya afinado su sensibilidad a la hora de considerar como analogías no tan extrafalarias las relaciones tejidas entre elementos aparentemente muy distintos, sobre todo si, como hemos visto con respecto a las relaciones entre Prada y Ramón, el autor utiliza técnicas y temas ya usados por otros.

34. Su pasión por Gómez de la Serna le llevará, quince años más tarde, a prologar una nueva edición de El dueño del átomo, publicada en 2011 por la editorial Berenice, de Córdoba.

35. Bonilla, luego, le dedicará a Gómez de la Serna un camafeo literario, recogido en el volumen La plaza del mundo (2008: 153-157), en el cual afirma que el escritor madrileño "[q]uería hacer un nuevo diccionario, definir poéticamente las cosas, convertirlas, como si no lo fueran ya, en imágenes sorprendentes" (155). 
Fiel a dichos preceptos, y entregado también a una labor poética que conlleva una mayor atención por los vocablos en cuanto mezcla de sonido y significado ${ }^{36}$, es obvio que el autor jerezano adopte una perspectiva más polifacética respecto a Prada, recurriendo a variantes gregueríacas que este último no había abordado y que se caracterizan por una marcada afición a la carambola léxica o conceptual. Pero antes de adentrarnos en el análisis de los textos bonillanos, hay que advertir que en su obra narrativa ${ }^{37}$ volveremos a manejar greguerías "intratextuales", aunque su presencia, con el sucederse de los títulos publicados, se ha vuelto más esporádica, como si fuera el eco de una lección asimilada en sus primeros tanteos para afinar una voz aún en busca de su propio timbre, sobre todo en el laberinto de la novela, un terreno que Bonilla (2008: 156) reconoce insidioso si se quiere seguir el ejemplo ramoniano: "Las novelas de Ramón hacen agua siempre porque empiezan sorprendiendo, pero acaban expulsando nuestro interés cuando el afán acumulativo y la falta de columna vertebral hacen que sus muñecos se caigan al suelo dejando un charco inevitablemente hecho de greguerías".

La influencia de Gómez de la Serna será entonces más patente en los libros redactados entre 1994 y el comienzo del nuevo milenio, un periodo de afianzamiento que se inaugura con El que apaga la luz (1994) y termina con La noche del Skylab (2000), colecciones de cuentos a las que hay que añadir El arte del yo-yo (1996) y La compañía de los solitarios (1999), la nouvelle Yo soy, yo eres, yo es (1998) y las novelas Nadie conoce a nadie (1996) y Cansados de estar muertos (1998). Allí, como en Prada, encontramos metáforas atributivas - "Las fronteras son las cicatrices con que la Historia va marcando la piel del Planeta" (Bonilla 2000: 12); "Los niños son adultos que tienen los ojos abiertos" (Bonilla 1998: 206); "las horas son un tren de mercancías que arrastra por la herrumbre de mi insomnio la promesa de una estación en la que descansar" (Bonilla 1999: 50-51); etc.-, metáforas aposicionales -“el sol, ese fumador empedernido" (Bonilla 2000: 13); "El sol de primavera, una moneda de ceniza compacta" (Bonilla 1996b: 165) 38; "sol, ese muchacho que salta

36. Hasta la fecha ha publicado los libros de poemas Partes de guerra (1994), Multiplícate por cero (1996), El belvedere (2002), Buzón vacío (2006), Los invisibles (2008), Cháchara (2010) y la antología Defensa personal (2009).

37. Su obra poética merecería un estudio más profundizado que por razones de espacio y coherencia -las obras de los demás autores pertenecen todas al ámbito de la narrativa- no consideramos oportuno incluir en estas líneas.

38. Aquí el autor retoma una estructura sintáctica y metafórica usada por Gómez de la Serna (1962: 101): "Sol de invierno en París es una tortilla a la francesa que nos llega fría". Obviamente, en la greguería ramoniana hay una dosis de humor añadida, porque Ramón juega con el término "tortilla a la francesa" y lo hace coincidir, no por casualidad, con el sol de París. 
una tapia de sombras y luego coge impulso para cruzar el cielo con una zancada de dieciséis horas que lo depositen tras otra tapia de sombras" (Bonilla 1998: 239) 39 ; etc.-, metáforas que se podrían colocar bajo el membrete de "puras" (Serrano Vázquez 1991: 210) -“Los espejos están hechos de cuchillos" (Bonilla 1996b: 13); "El cielo de la mañana tiene el color de la cabellera anciana de un sabio hindú" (Bonilla 1998: 153) 40; "el foco policial de la luna" (Bonilla 2003: 221) ${ }^{41}$; etc.- y símiles -“trenes obsoletos cuyos vagones se unen por esos grandes fuelles que suenan como férreos acordeones que a lo largo del viaje van gimiéndole a los viajeros el desgarrado tango de la distancia" (Bonilla 1996: 7) 42, "Los copiosos árboles de la Avenida [...] alzan sus puños verdes al cielo como un desfile de revolucionarios" (Bonilla 1998: 39) $)^{43}$; "El viento, como un perro incomodado por las pulgas, se rasca el lomo en todas las esquinas" (209) 44 $^{4}$ etc.-. Pero a partir de los ejemplos brindados es posible vislumbrar una peculiaridad que distingue a Bonilla de Prada, o sea su tendencia a emplear la prosopopeya ${ }^{45}$ sin que esto implique necesariamente su contrario: la reificación de lo humano. Las razones de este hecho, probablemente, estriban en la forma en que se ha aproximado a las greguerías de Ramón, cuya esencia, para él, "consiste en pasar por la plataforma de su lente de aumento los objetos cotidianos y hacernos ver que no son tan vulgares como creíamos" (Bonilla 1996a: 235).

Este enfoque aleja a Bonilla de lo grotesco y lo cáustico, orientando su pluma hacia lo poético y lo humorístico ${ }^{46}$ que se mantienen en tensión entre un estilo a

39. La personificación del sol y la visión del horizonte como un obstáculo que hay que superar de un brinco son elementos ramonianos: "Amanecer: el sol salta la garrocha del horizonte" (Gómez de la Serna 1962: 1510).

40. Ramón, en cambio, había trabado una correspondencia entre el color del día y el de los telegramas: "El día tenía un color azul de telegrama" (Gómez de la Serna 1962: 587).

41. La luna es un elemento recurrente en las greguerías y quizás Bonilla puede haberse inspirado en algunas de éstas: "La luna es el ojo de buey del barco de la noche" (Gómez de la Serna 1962: 231); "La luna es el ojo de cristal del cielo" (286); "La luna está subvencionada por la Policía" (524).

42. Los hilos que unen los trenes, los viajes y el tango ya habían sido trenzados por Ramón: “En los fuelles que unen los vagones del tren se oye el tango del viaje" (Gómez de la Serna 1962: 348).

43. La imagen podría ser un eco de la fusión de dos asociaciones ramonianas: "Las patatas cierran el puño debajo de la tierra" (Gómez de la Serna 1962: 105) y "Al internarse en el bosque se encuentran árboles que están haciendo servicio militar obligatorio” (1407).

44. Esta es casi una cita de Gómez de la Serna (1962: 110): "El viento se rasca la espalda en las esquinas".

45. He aquí otros ejemplos de personificación en Bonilla: "Me dormí, pero enseguida oí el murmullo del día desperezándose" (Bonilla 1996: 34); "El mar se reía a carcajadas de mi desgracia con olas gigantescas" (Bonilla 1999: 103); "una mesa completamente inutilizada por el ejército de tacitas de plata y jarroncitos minúsculos que formaban sobre ella” (Bonilla 2003: 140); etc.

46. A menudo se ha destacado la vis lúdica de Bonilla (Sánchez Magro 1996: 34; Manilla 1997: 73; Turpín 1999: 70; Cabré 2000: 75), algo que también para Gómez de la Serna (1962: 44) era fundamental: 
veces barroquizante, que añade demasiadas circunvoluciones a las que hubieran podido ser eficaces greguerías - "El firmamento mercadeaba sobre su manto índigo las últimas baratijas, el resto del saldo nocturno, donde destacaba la barcaza de la

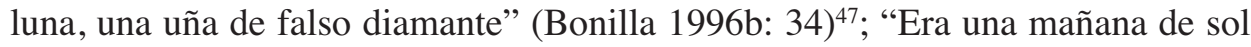
pletórico, con un pequeño rebaño de nubes esculpido sobre la carne del horizonte" (Bonilla 1999: 63); etc.-, y una notable propensión al exabrupto ingenioso que se resuelve en una comparación estrafalaria, una hipérbole paradójica o una reacción en cascada de paronomasias o juegos de palabras. Es precisamente en este ámbito donde el autor obtiene sus mejores logros y muestra haber llevado a cabo una reelaboración personal de los malabarismos propios de Gómez de la Serna.

Nuestro periplo entre los trampantojos de la lengua podría comenzar con una forma básica de socavar el significado convencional de los vocablos: la definición, un recurso muy parecido al de la metáfora atributiva o aposicional que, a través de la sintaxis de los diccionarios, se propone desvelar la ceguera de estos últimos en su tarea de definir el corazón oscuro de las palabras; he aquí un par de ejemplos: "laberinto: es una pared que da demasiadas vueltas tratando de salir de sí misma" (Bonilla 1996b: 31); "El amor: acaparar las acciones del otro, en eso consiste" (Bonilla 2004: 106) ${ }^{48}$; etc. Sólo hace falta volverla del revés para que de ella derive la fórmula del acertijo, una construcción empleada con frecuencia por Ramón (Serrano Vázquez 1991: 78-79) y que Bonilla retoma en Nadie conoce a nadie para crear un ingenioso crucigrama literario:

\footnotetext{
"Este Rey Midas todo lo que toca lo convierte en moro (Solución: Goytisolo).", "Este poeta tiene nombre de ginebra con la que arde el mar" (Solución: Gin Ferrer).", "Es pequeño, peludo y suave, casi de algodón (Solución: Arrabal).", "Sus memorias se titularían La maté porque era Mia... Farrow (Solución: Woody Allen).", "Es el arte Marcial por excelencia (Solución: el epigrama)" (Bonilla 1996b: 24).
}

\footnotetext{
"Dediquémonos a la diversión pura y diáfana, que defiende la vida y la aúpa. [...] El día en que la vida esté llena de diversiones se habrá acabado el rencor maligno y todos los monstruos que crea el aburrimiento".

47. Entre las greguerías de Ramón hay unas que podrían haber servido de modelos a Bonilla: "El cielo estrellado de la noche había sacado brillo a sus sortijas frotándolas contra su frac azul" (Gómez de la Serna 1962: 351); "El cielo se toma todos los días el gran trabajo de retirar todas sus joyas de la vidriera de la noche en cuanto siente que viene el ladrón del alba" (1332) y "El manto azul de la noche está apolillado de estrellas" (1561).

48. Ramón, en repetidas ocasiones, había construido sus greguerías alrededor de dicha estructura: "Sortilegio: una palabra con sortijas" (Gómez de la Serna 1962: 142); "Rallador: aparato para torturar al queso" (192); "Soda: agua con hipo" (583); "Ventilador: rosa de los vientos mecanizada" (687); etc.
} 
En estas líneas se observan varios rasgos ramonianos. Lo primero que llama la atención es que todos los ejemplos remiten a nombres propios de artistas que resultan ser el blanco de las burlas del autor y esto es algo que ya Gómez de la Serna había experimentado ${ }^{49}$, estableciendo a menudo "una relación lógica entre el significante y significado, interpretando el significante de un nombre en correspondencia con otro signo de la lengua, del cual pasará a tener su significado" (Serrano Vázquez 1991: 82). Aquí dicha técnica se aplica a la segunda, la cuarta y la quinta adivinanza y es llevada al extremo, puesto que todas ellas se sustentan en una dilogía cómica ${ }^{50}$. De hecho, la traducción inglesa del término "ginebra" le sirve al autor para ofrecer una versión ligeramente distorsionada del apellido del poeta Pere Gimferrer; luego el nombre de Mia Farrow es aprovechado para crear una confusión con el pronombre posesivo femenino singular "mía" y, luego, el apellido del epigramista latino Marco Valerio es empleado como si fuera el adjetivo que normalmente se utiliza para referirse a técnicas de lucha procedentes de Extremo Oriente. Las restantes greguerías bonillanas, en cambio, están planteadas a partir de una paronomasia implícita ("oro" y "moro") -sugerida por la presencia evocadora del mítico Rey Midas y por la fascinación que lo árabe ejerce sobre Juan Goytisolo- y por un uso insólito de una conocidísima frase literaria (la descripción de Platero en Platero y yo de Juan Ramón Jiménez) que, sacada de su contexto, se convierte en una manera graciosa de proporcionar un escueto retrato físico de Fernando Arrabal. Sin embargo, no se trata de excepciones en la prosa de Bonilla y en otras ocasiones los nombres propios o los títulos de algunas obras vuelven a ser víctimas de la paronomasia: "Este Junot es una joya: la joya del Nihilo" (Bonilla 2004: 97); "Karl Marx, que fue el Mago de Hoz y el Martillo" (Bonilla 1996a: 173); etc. Pero quizás sea preciso volver a Nadie conoce a nadie para darse cuenta de hasta qué punto el escritor jerezano se complace en rizar el rizo de su humorismo:

María me dijo que su escritor favorito era Fernando Savater y [...] yo le dije que últimamente se había hamburguesado y convertido no sabía bien si en un escritor de peso o en un pesado. [...] y dije por ejemplo que Umbral escribía en un proustíbulo y puestos a buscar el tiempo perdido preferible era perder el tiempo en Combray que en sus escombros (Bonilla 1996b: 142).

49. “‘Tintoretto! La mejor tintorería del arte” (Gómez de la Serna 1962: 724); “¿Cuál es la mujer más antigua? Antígona" (1180); "Morfeo: el que se mofa del sueño" (1456); etc.

50. La dilogía era otra ganzúa, a veces combinada con la paronomasia, usada por Gómez de la Serna para obtener efectos cómicos (Serrano Vázquez 1991: 86): "Arrójate a la nada y nada" (Gómez de la Serna 1962: 812); "Comienzan saltando los bancos y acaban asaltando los Bancos" (1544); etc. 
Es fácil notar que Marcel Proust le ofrece el diestro para acuñar el neologismo "proustíbulo", una agudeza construida por derivación ${ }^{51}$-procedimiento explotado también por Ramón (Senabre 1967: 138; Serrano Vázquez 1991: 121-125)-, recurriendo al apellido del escritor francés y al sufijo "-bulo" para evocar el parónimo "prostíbulo" y al mismo tiempo para ilustrar en una única palabra el estilo y los temas de Umbral. Algo parecido pasa con "hamburguesado", donde un préstamo del inglés -"hamburguesa"-, siguiendo el modelo del verbo "aburguesarse", recibe el sufijo "-ado", típico del participio, y sintetiza la evolución ideológica y física del filósofo Savater. A todo esto Bonilla añade tres juegos de palabras -no exentos de cierto valor de crítica literaria- orquestados alrededor de una voltereta conceptual con respecto al título de la obra de Proust - "puestos a buscar el tiempo perdido preferible era perder el tiempo"- o de la aliteración -“en un escritor de peso o en un pesado", "Combray" y "escombros"-, otra arma estilística esgrimida por Gómez de la Serna con tan acertada destreza en la fusión de los aspectos sonoros y semánticos de los términos que el significante en muchas ocasiones se convierte en complemento del significado (Gómez Yebra 1994: 34-35) ${ }^{52}$.

Tampoco el funambulismo del escritor jerezano puede desligarse de esta interacción, ya que es justamente en sus entresijos donde queda patente la comicidad de las convenciones linguiísticas: de hecho, es suficiente utilizar en sentido ambiguo una palabra polisémica o cambiar una letra o desplazar una sílaba de un lugar a otro para obtener un efecto humorístico. De ahí que la figura de dicción más usada por Bonilla sea la paronomasia, un recurso que le permite recoger el testigo de Ramón, el cual la había aprovechado abundantemente para descubrir asociaciones azarosas y para romper con la banalidad de la lengua (Senabre 1967: 136-139; Fernández García 1990: 188; Serrano Vázquez 1991: 83-88; García Yebra 1994: 35)³3. No conformándose con usar la paronomasia sólo de forma tradicional -“las mayorías son ruidosas, y también ruinosas" (Bonilla 1996a: 179); "es un sello del lugar y lo mejor que puede hacerse no es atacarlo, sino acatarlo" (Bonilla 1996b:

51. "Entendemos por derivación toda formación léxica que se produce por la combinación de una base (palabra o tema) con afijos (prefijo o sufijo)" (Serrano Vázquez 1991: 121).

52. También en el caso de Bonilla no se trata exclusivamente de engendrar un efecto fónico, puesto que el espacio imaginario de Combray, creado por Proust, es asociado a los "escombros" producidos por la pluma de Umbral, en una reflexión crítica que considera al escritor madrileño como un epígono decadente del autor francés.

53. He aquí algunas greguerías ramonianas construidas a partir de la paronomasia: "Lo peor que oye uno es cuando el médico nos dice que estamos descalcificados. Sólo estar descalificados es peor" (Gómez de la Serna 1962: 131); “¿Qué fácil es que el adulto pase a ser adúltero” (393); "Los gorriones son unos gorrones” (695); “Algunos plagios son sólo hemiplagios, pero ya queda bien el hemipléjico” (937); etc. 
89)-, el autor de Nadie conoce a nadie la combina con otras técnicas ramonianas como la representación tipográfica (Serrano Vázquez 1991: 102), si bien sin basarse en el diseño de las letras del alfabeto o de otros signos, sino en la grafía de la palabra, a través de una paronomasia implícita: "Todo el mundo lo sabe: tarde o temprano a la rutina se le cae la t" (Bonilla 1998: 39) ${ }^{54}$. De vez en cuando, recurre a ella también para desactivar la sentenciosidad de oraciones de uso corriente, locuciones, frases bíblicas y refranes, elementos ya desestabilizados por Gómez de la Serna (Serrano Vázquez 1991: 108-111). Este aspecto, aunque no tan frecuente en la escritura bonillana, merece ser analizado con un poco más de detenimiento porque constituye un rasgo de originalidad entre los autores noveles de los años 90 del siglo XX y porque es un estilema de clara matriz ramoniana.

Si consideramos la siguiente oración: "Es por eso tal vez que la realidad supera a la ficción: porque la ficción supura realidad” (Bonilla 1996a: 236), no es nada difícil darse cuenta de cómo Bonilla mina una aserción muy manida valiéndose de la paronomasia para darle nuevo lustre, añadiendo un deje aforístico al obrar una inversión conceptual -parece contradictorio que la ficción "supure" realidad-que no sólo obliga a interrogarse sobre el estatuto de lo ficcional, sino que expresa un pensamiento dotado de cierta validez universal, puesto que la mayoría de las historias fantásticas, en efecto, suele tomar impulso de sucesos reales. Otra muestra de rebelión contra los clichés de la lengua lo encontramos en "El tabaco es la principal causa de las estadísticas" (Bonilla 1998: 75-76), donde el autor da la vuelta a una expresión habitual, jugando con el afán estadístico que el consumo de tabaco despierta en los organismos sanitarios, y sustituye la que hubiese tenido que ser la conclusión extraída de los datos recogidos - pongamos "el tabaco es la principal causa del cáncer pulmonar"- precisamente con el procedimiento mediante el cual se ha llegado a tal afirmación, o sea las estadísticas; de ahí que la comicidad surja, como en Gómez de la Serna, de la translación de "la expresión natural de una idea a un tono diferente" (Serrano Vázquez 1991: 104) que aquí genera un efecto cómico gracias al círculo vicioso engendrado por la la frase, una espiral donde el tabaco y las estadísticas se persiguen en la vana tentativa de llegar al desenlace lógico que subyacería a la estructura "Las estadísticas dicen que el tabaco es la principal causa de...". Sin embargo, Bonilla no se limita a dinamitar las frases estereotipadas, sino que se enfrenta también al reto de desbarajustar las locuciones, aprovechando nuevamente la paronomasia implícita -"Esta es época de becas flacas" (Bonilla

54. Gómez de la Serna (1962) había hecho algo parecido: "Escribía 'habrigo' con hache, porque así resultaba más abrigado" (96); "Lo malo es cuando el amor del hombre pierde la erre" (1572); etc. 
1996b: 53) - o aplicando a rajatabla la fórmula ramoniana de tomar al pie de la letra uno de los componentes de la expresión para desencadenar la greguería (Serrano Vázquez 1991: 110-111), como en "La gran tragedia de una vida: no tener una guerra donde caerse muerta [...]. Hay hombres que sólo saben ver las estrellas cuando les dan un puñetazo" (Bonilla 1998: 76), ocurrencias ingeniosas en las que la interpretación literal de "donde caerse muerto" y "ver las estrellas" prevalece sobre su sentido figurado y permite una reelaboración cómica de las mismas ${ }^{55}$.

La voluntad de medirse con construcciones todavía más arraigadas en las costumbres lingüísticas lleva luego a Bonilla a seguir las huellas de Gómez de la Serna en su manía por reescribir frases proverbiales o refranes (Senabre 1967: 140-141; Fernández García 1990: 189; Serrano Vázquez 1991: 108-109; García Yebra 1994: $40)^{56}$ y aunque los resultados son escasos desde el punto de vista cuantitativo, nos parecen de todos modos significativos. La enseñanza evangélica "bienaventurados los pobres en espíritu, porque de ellos es el reino de los cielos" se trastoca en "bienaventurados los amantes posesivos porque de ellos será el reino de los celos" (Bonilla 1996b: 111) ${ }^{57}$, agudeza producida por la paronomasia "cielos/celos" que provoca el obligatorio cambio de los destinatarios de la alocución, con el consiguiente desplazamiento del campo espiritual al amoroso. Siempre por medio de dos términos parónimos -entre los que el original permanece implícito-, asistimos a la transformación del refrán "del dicho al hecho, hay un buen trecho" que transpuesto en el ámbito de las relaciones sentimentales adquiere un matiz muy diferente: "En cuanto al amor la vida me ha enseñado un par de cosas: que del dicho al lecho siempre hay un buen trecho" (Bonilla 1996a: 228). Aquí no tenemos una modificación de la estructura del refrán propia de las greguerías de Ramón (Serrano

55. Este tono burlón es una clara reminiscencia del empeño ramoniano en ridiculizar locuciones o frases estereotipadas: "Tener un mar de dudas y un mar de deudas: naufragio seguro" (Gómez de la Serna 1962: 794); "Un mal pianista cumple con exactitud eso de 'serán ejecutados sin interrupción"” (1033); "La mejor manera de que no sea fatal el morir es no tener donde caerse muerto" (1290); etc.

56. Otro hilo capaz de unir la prosa de Bonilla a la de Gómez de la Serna podría ser el de la hipérbole estrafalaria o hilarante. Ramón la utilizaba con frecuencia (García Yebra 1994: 41), sobre todo explotando la construcción "tan... que": "Era tan compasiva que le hizo una bufanda al termómetro del balcón" (Gómez de la Serna 1962: 292); "Era tan independiente que tomaba la sopa con un cuchillo" (817); "Era tan pobre que tenía que soñar sueños de segunda mano" (932); etc. El escritor jerezano también tantea sus potencialidades humorísticas o poéticas: "tenía tanto sueño que si hubiera tenido que acogerme en un hotel hubiera pedido una habitación doble" (Bonilla 1996a: 283); "El cerebro de las jirafas se siente tan solo que ha olvidado ordenar sonrisas" (Bonilla 2004: 49-50); etc.

57. Una greguería ramoniana que podría hacer el par con la de Bonilla es "Levántate y lávate" (Gómez de la Serna 1962: 812), si bien aquí el recurso que invita a la risa no es la paronomasia, sino el contraste entre lo extraordinario de la resurrección y lo anodino de la rutina diaria. 
Vázquez 1991: 108), pero sí contamos con una alteración lúdica de su sentido con fines humorísticos. Como señalan Senabre (1967: 141) y Serrano Vázquez (1991: 111), además de socavar los cimientos de una lengua anquilosada, Gómez de la Serna se dedica a renovar el horizonte lingüístico inventando fórmulas paremiológicas $^{58}$, un mecanismo que también Bonilla intenta imitar, rozando la reflexión melancólica -"Envejecer consiste en dejar de fantasear con el futuro para empezar a fantasear con el pasado" (Bonilla 1999: 185)-y, obviamente, el humor: "Dios es a la filosofía lo que el hambre a la gastronomía" (Bonilla 1996a: 144)

A estas alturas parecen entonces claros los caminos de Prada y Bonilla, unos senderos que tienen un origen común en la huida de la telegráfica escritura realista de muchos de sus coetáneos -fuga similar a la del fundador de las tertulias del café Pombo (Nicolás 1988: 131) ${ }^{60}$-, pero que se bifurcan a la hora de manejar la greguería porque, más allá de un impulso poético compartido y un gusto por un estilo trabado, el primero elige la vía de una causticidad que no deja títere con cabeza en su afán por hiperestetizarlo todo a través de una lupa demoledora, mientras que el segundo se aferra a una experimentación lúdica que le permite adentrarse a fondo en los vericuetos del lenguaje. De este modo, la escritura bonillana y la pradiana se inscribirían de lleno dentro del legado que Gómez de la Serna, según Ródenas de Moya (2003: 36), dejó a las generaciones venideras, o sea esa "capacidad para desorganizar con la escritura nuestra rutinaria y entumecida percepción de la realidad"; aunque, como ya hemos

58. Ejemplos de dicha técnica son: "Cartas que no llegan corazón que descansa" (Gómez de la Serna 1962: 745); "Nada retorna pero todo se parece" (1161); etc.

59. Ambos pueden considerarse refranes porque como subraya Serrano Vázquez (1991: 107), citando a Cases, "El refrán se diferencia de la frase proverbial en que el que inventa un refrán aspira a formular en forma abstracta, [...], una 'verdad' valedera para toda la humanidad, sin distinción de tiempos ni lugares" y en los ejemplos bonillanos tenemos esa universalidad abstracta que, para más señas, se construye a partir de estructuras breves y unos paralelismos - “dejar de fantasear con el futuro"/“empezar a fantasear con el pasado"; "Dios"/“hambre" y "filosofía"/“"gastronomía"- que no sólo se ajustan a la lengua hablada sino que facilitan su memorización, en el segundo caso incluso por medio de la rima.

60. A este propósito, pese a las afinidades conceptuales entre Prada, Bonilla y Ramón en su condena de una representación excesivamente realista del mundo, no deja de sorprender el contraste que se establece entre ellos en el ámbito de su producción novelesca porque "La ramoniana es una novela más bien corta, formada por bastantes capítulos cortos; capítulos cortos constituidos a su vez por párrafos cortos y estos compuestos también de oraciones cortas" (López Molina 2008: 131), mientras que las novelas pradianas y bonillanas en general abogan por una extensión notable tanto en su totalidad como en sus distintas partes, pero quizás dicha disparidad se debe a sus reacciones a las estéticas predominantes en los respectivos momentos históricos: si la novela realista decimonónica acostumbraba a ser larga y plagada de detalles, Gómez de la Serna podía desbarajustarla sólo recurriendo a una escritura poética y fragmentaria; en cambio, Bonilla y Prada, al rehuir de una prosa generalmente escueta, casi de guión de cine (Navarro Martínez 2008: 61-62), apuestan por una profusión verbal de raigambre barroca. 
resaltado, las desmitificaciones de Prada han acabado por convertirse en una costumbre estilística sintomática de cierto estancamiento tanto ideológico como literario y la pirotecnia de Bonilla ha ido diluyéndose a lo largo de su producción narrativa.

A dichos trayectos es posible arrimar el de Ray Loriga que, si bien a primera vista parece muy diferente respecto a los dos anteriores, traza unas directrices no tan alejadas de ellos, puesto que se distingue del de Prada y de Bonilla por el hecho de seguir una dirección contraria que, en vez de alejarle progresivamente del magisterio de Gómez de la Serna, lo aproxima a éste de forma inconsciente -el autor no ha aludido nunca a una posible influencia, directa o indirecta, del inquieto grafómano madrileño- a través de la admiración por la arisca narrativa norteamericana (Juristo 1994: 51), la música rock, una extremada sensibilidad audiovisual y un lirismo venado de imágenes naif. Las bases de esta evolución se encuentran en su primer libro, Lo peor de todo (1992), un texto fragmentario que relata la existencia de Elder Bastidas -un abúlico adolescente que se resiste a crecer y aceptar las convenciones de la vida adulta- mediante un espacio narrativo que "organiza la yuxtaposición de elementos, no según nexos causales, ni siguiendo el hilo de una cierta asociación de ideas, sino en función de afinidades "tonales"' (Sacristán 1992: 64). Obviamente, una estructura tan poco cohesa se presta a ser "interrumpida caprichosamente [...] con fogonazos líricos o aforismos gregueríacos" (Gracia 2005: 263), pero, como señala Navarro Martínez (2008: 182), no se trataba de pisar las huellas ramonianas, sino que era una forma de jugar con el formato de la canción rock, un género muy interiorizado por Loriga ${ }^{61}$ y que será medular en Héroes (1993), cuyo título y cuya dedicatoria a Ziggy Stardust remiten a David Bowie (Steenmeijer 2004: 61).

El interés del escritor por la música, sin embargo, no es algo contingente, sino que supone "un agudo rechazo de la identidad impuesta por la familia, el momento histórico y las circunstancias" (59), una actitud iconoclasta que, a pesar de no buscar una salida radical del sistema (Gracia 2005: 261), se contrapone al ideal pequeñoburgués, reproduciendo de este modo, en clave contemporánea, la aversión de Gómez de la Serna por los valores burgueses de su tiempo (Serrano Vázquez 1991: 35): de ahí que la fuga de Loriga hacia la canción como tabla de salvación ${ }^{62}$ pueda

61. "Lógicamente yo tengo influencia anglosajona porque no he oído en mi vida un disco de Antonio Molina y sí tengo todos los discos de Rolling Stones. [...] Mis raíces son los Rolling Stones” (Martínez 1993: 38). Navarro Martínez (2008: 81) hipotiza además que la novela experimental Tarantula de Bob Dylan habría podido influir en la escritura del autor.

62. El narrador de Héroes expresa claramente su convicción de que las estrellas del rock pueden resguardarle de los peligros de la existencia: "Bien, estoy aquí metido, en mi cuarto, y las canciones van 
coincidir con el acto ramoniano de atrincherarse detrás de la inspiración literaria. El autor entonces, guiado por su sensibilidad y absorbiendo los aires que impregnaban cierta literatura de los $90^{63}$, apuesta por una prosa que se amolda a las cadencias del rock y concibe Héroes como un conjunto de letras de un hipotético disco (Navarro Martínez 2008: 155; Valencia 2008: 19), donde las frases adquieren una mayor contundencia y los pensamientos una sentenciosidad de "hierro y azúcar" (Echevarría 1993: 11) que se convertirá en una de las marcas estilísticas de Loriga, muy evidente también en Días extraños $(1994)^{64}$. Es justamente en estas dos obras donde abunda el deje gregueríaco, aunque el autor, contrariamente a Prada, Bonilla y al mismo Ramón novelista (López Molina 2008: 135), insiste más en las metáforas puras y menos en las asociaciones, quizás porque las primeras se ajustan mejor al carácter poético y narrativo de las canciones, ya que las imágenes insinuadas encierran un mayor poder evocador y también una velada melancolía, sentimiento muy característico de ciertos géneros musicales - un claro ejemplo es el grunge de grupos como Nirvana, cuyo líder Kurt Cobain ocupa un lugar prominente en la mitología personal del escritor (Gracia 2005: 259; Navarro Martínez 2008: 202-208) - y de la prosa de Loriga (Gracia 2005: 259; Cattaneo 2012: 8990): "Los sueños que se adaptan a las circunstancias no son sueños, se llaman anuncios y los utilizan para fastidiarte las películas" (Loriga 1998: 169); "Las manos de las fotografías no son mis manos. Las manos de las fotografías sujetan las cosas, pero las manos del recuerdo las dejan caer. Las manos del recuerdo dejan que todo se escape" (Loriga 1994: 22) 65; "El dueño del daño lleva un cuchillo grande que encaja en tu carne como un zapato a medida. Tiene las manos del tamaño de tus guantes y sus ojos sólo ven a través de tus gafas" (103) ${ }^{66}$; etc. Pero quizás lo que más llame la atención es la fascinación que el autor siente por las mujeres y los

saliendo y yo sólo espero que no me dejen tirado, espero de las canciones todo lo que no me han dado mis padres [...]. Espero poder andar por encima de mis canciones más tranquilo de lo que andaba por encima de los pasos de los demás" (Loriga 1998: 63).

63. El tema de la música en la literatura de la década de los 90 ha sido tratado detenidamente por Navarro Martínez (2003, 2008: 133-210) y para ulteriores profundizaciones remitimos a sus ensayos, puesto que aquí nos centramos exclusivamente en la obra de Loriga. También el mismo Bonilla (1996c: 8) había resaltado que en los textos de sus coetáneos no era raro toparse con "algún chispazo lírico muy típico de las canciones de Joaquín Sabina o Tom Waits".

64. El título del libro es un evidente homenaje al disco Strange Days del grupo The Doors.

65. La dicotomía entre manos reales que pueden agarrar las cosas del mundo y manos fantasmales que no pueden entrar en contacto con la vida parece una resonancia ramoniana: "Lo malo de las preciosas manos de los cuadros es que no pueden volver al mundo. Cambiarían su estar en el Museo por estar en la vida" (Gómez de la Serna 1962: 1010).

66. Aquí Loriga recurre a una evidente paronomasia: “dueño” y "daño". 
niños -temas frecuentes de las greguerías de Gómez de la Serna y normalmente representados por él según una óptica burlona o admirativa ${ }^{67}$, que considera seres ideales -los primeros representan la irrecuperable pureza de la infancia, mientras que las segundas son figuras casi angelicales (Cattaneo 2012: 96-98)-: "la más pequeña de las mujeres tiene faldas y pies y respuestas tan extrañas como dormir al lado de un cañón" (Loriga 1998: 42); “Todas las noches tienen cuerpo de mujer y cola de pez, pero al final sólo te acuerdas de las sirenas de los bomberos" $(90)^{68}$; "Los niños duermen porque agotan todo su tiempo, se lo tragan" (Loriga 1994: 22); "Los niños se visten de blanco y juegan al fútbol sobre su propio reflejo mientras baja la marea como si quisieran entrar por la fuerza en todos los poemas" (86); etc.

Junto a estos relámpagos poéticos, hay otros surgidos de unas metáforas atributivas - "Las cosas de los muertos son en realidad las manos de los muertos, la caricia helada de lo que no está" (Loriga 1994: 77); "Las gaviotas son los monos del cielo" (88) ${ }^{69}$; "El miedo es un vendedor puerta a puerta. El miedo es un abrelata teledirigido. El miedo es una carpa sobre un circo vacío. [...] El miedo es un tonto con un martillo" (101) ${ }^{70}$; etc.- o de unos símiles - "Las ferias son un poco como los circos, sólo las echas de menos cuando se van" (Loriga 1994: 14)71, "La sonrisa del extranjero es como la linterna de un imbécil, siempre encendida, de día y de noche" (84); etc.-, entre los cuales se distinguen algunos que, por su concisión aforística, se aproximan a las paradójicas frases proverbiales de ascendencia ra-

67. "No hay nada más conmovedor que la risa de una mujer bella que ha llorado mucho" (Gómez de la Serna 1962: 208); "Cuando baja una mujer por una escalera de caracol parece haber sido despedida del paraíso" (319); "Si os tiembla la cerilla al dar lumbre a una mujer, estáis perdidos" (537); "El sueño de la mujer es belleza: por eso no ronca" (637); etc.; "En las cajas de lápices guardan sus sueños los niños" (502); "Cuando el niño corre detrás de la resaca se cree que el mar huye de él” (639); "Los niños comen los barquillos con tanto afán porque son como los tirabuzones rubios de las niñas" (1303); etc.

68. La primera greguería de Loriga apunta a representar a la mujer, incluso a la más pequeña, como un rompecabezas insoluble ejemplificado por una imagen surrealista - "dormir al lado de un cañón”-, mientras que en la otra el autor juega con una dilogía implícita -la "sirena" como ser mitológico y la "sirena" como aparato sonoro- para subrayar la imposibilidad de retener tanto las noches como a las mujeres que deslumbran a quien narra. Quizás haya una reminiscencia de esta greguería ramoniana: "La mujer ama los adornos que tienen lentejuelas, porque le gustaría tener frescas escamas de pez" (Gómez de la Serna 1962: 109).

69. Una metáfora atributiva muy parecida entre animales había sido usada también por Gómez de la Serna (1962: 194): "Los halcones son los perros de caza para el cielo".

70. Loriga, para definir el miedo, emplea las técnicas ramonianas de la personificación -“es un vendedor puerta a puerta"; "es un tonto con martillo"- y de la cosificación -"es un abrelata teledirigido"; "es una carpa sobre un circo vacío"-.

71. Se encuentra la misma melancolía ligada al circo en un símil ramoniano: "Los carteles de cine mueren como carteles de circo" (Gómez de la Serna 1962: 1333). 
moniana: "Los consejos no son más que una forma de muerte prematura y hereditaria" (Loriga 1998: 65) 72, "La muerte es innecesaria como todo lo inevitable" (Loriga 1994: 121); etc.

Si tomamos en consideración las oraciones lapidarias de Loriga a la luz de lo dicho hasta ahora y de los ejemplos ofrecidos, vemos que la vertiente humorística se troca siempre en una ironía venada de amargura, en una prosa con una "propensión al aforismo de estirpe lírica, a menudo onírica o irracionalista, [...] pegada a [...] puntos de vista menores extrañamente solidarios con la tristeza" (Gracia 2005: 265). Este tono comedido y nostálgicamente rebelde se obtiene por medio de un roce continuo entre la inmediatez de la canción y la plasticidad de la poesía que produce una greguería más áspera, a mitad de camino entre la admonitoria dureza aforística y la sorpresiva imagen metafórica, acercándose a los chispazos más sombríos de Gómez de la Serna ${ }^{73}$. La expresión escueta de una pesadumbre existencial nos permite acercar todavía más la greguería al verso de un buen cantautor, ya que en ambos casos hay un mecanismo de reacción a unos estímulos artísticos que no implica para el receptor un esfuerzo desmedido a la hora de asimilar el mensaje y de experimentar un placer estético: la "recompensa", como recuerda Gómez Yebra (1991: 41) al examinar los origami de tinta y papel de Ramón, "es inmediata”.

En las entregas sucesivas, a partir de Caídos del cielo (1995), Loriga, como Bonilla, tratará de refrenar su pasión por semejantes hallazgos (Cattaneo 2012: 99121), en busca de un equilibrio entre sentenciosidad e historia narrada ${ }^{74}$, pero éstos, aunque más esporádicamente, seguirán alumbrando sus páginas: "Morirse es como quedarse dentro del tren cuando ya ha pasado tu parada" (Loriga 1995: 75) 75; "La memoria es el perro más estúpido, le lanzas un palo y te trae cualquier cosa" (Lo-

72. Ramón había escrito: "He notado que se dan consejos como se regalan los almanaques que sobran, para salir de ellos" (Gómez de la Serna 1962: 164).

73. "En el otoño, todo el campo está lleno de adioses" (Gómez de la Serna 1962: 315); "Los cigarros son los dedos del tiempo que se convierten en ceniza" (339); "Los espejos están azogados con los ojos muertos” (521); “El niño grita: ‘¡No vale!...' ¡Dos contra uno!’, y no sabe que toda la vida es eso: dos contra uno" (1102); etc.

74. "a mí me gustan los hallazgos sonoros. Pero también es verdad que hay cierto truco en eso. Una vez que lo tienes puedes repetir cosas muy sonoras y limitar el camino de otros trabajos literarios que te quedan por hacer [...]. Sí, es verdad, con el tiempo he intentado ir moderando eso porque las frases deslumbrantes, vistas con la distancia, pueden ser un poco fuego de artificio" (Valencia 2008: 21).

75. Los viajes en tren y la muerte, ya habían sido tratados por Gómez de la Serna: "Morirse es meterse por sorpresa en un vagón de carga vacío" (Gómez de la Serna 1962: 596); "Lo azorante del viaje de la vida es que no sabemos en qué estación nos tocará descender" (822). 
riga 2000: 60) ${ }^{76}$; "Si no hubiera mañana, [...] hoy no sería un problema tan serio" (Loriga 2008: 111) ${ }^{77}$; etc. Dicha evolución estilística repercute también en la estructura de sus libros ya que al limitar su habitual cadencia aforístico-gregueríaca en pos de una mayor trabazón de los textos se asiste a una tentativa de dotar las historias contadas de una cohesión que, sin renunciar a una perspectiva personal, supere el fragmentarismo de Lo peor de todo y Héroes (Gracia 2005: 263). En su primer libro los párrafos eran muy breves y la narración se desmigajaba en capitulillos de dos páginas o, como mucho, de ocho - con una única excepción de diecisiete páginas (Loriga 1999: 101-117)-, a su vez compuestos a menudo por fracciones de texto separadas por un espacio en blanco; mientras que su segundo volumen, al estar concebido como una colección de cuentos-canciones de media página o, a lo sumo, de cuatro folios, acentuaba la impresión de tener entre las manos un mosaico de diminutas teselas. Estos rasgos volverán a aparecer en Caídos del cielo, una novela que aspiraba a ser un cruce entre los libros de Jim Thompson y el nouveau roman de Robbe-Grillet y Marguerite Duras (Valencia 2008: 19) y que acabará por remedar la esbeltez del guión de una road movie (Pérez 2007: 160; Navarro Martínez 2008: 105-106), con capítulos muy cortos -van de las cinco líneas (Loriga 1995: 99) a un máximo de cuatro páginas- en los que se alternan oraciones lapidarias y diálogos lacónicos. Sin embargo, este último experimento narrativo, con una trama más lineal, le sirve a Loriga para cerrar su primera etapa de formación literaria que coincide con la definitiva superación de una dolida añoranza por el mundo de la infancia (Gracia 2005: 264; Cattaneo 2012: 94-95), y supone además la necesidad de encontrar una nueva voz que llegará a cuajar en Tokio ya no nos quiere (1999) (Romero 1999: 23) donde -a pesar de reincidir en el uso de fragmentos textuales hilvanados con frases concisas y una puntuación reducida casi exclusivamente al punto y a la coma- los párrafos, y sobre todo los capítulos, adquieren una extensión inusitada, secundando una repartición más clásica (Baños y Rosell 1999: 22).

El autor, de este modo, parece haber tomado un camino distinto al de Gómez de la Serna que, como se ha subrayado en repetidas ocasiones, abogaba por una prosa fraccionada, tejida mediante un "puntillismo sintáctico” (López Molina 2008:

76. La animalización paródica de un aspecto abstracto es otro rasgo ramoniano: "La inconsciencia es como la gallina que vuelve a poner el huevo donde se lo han robado" (Gómez de la Serna 1962: 815).

77. Ramón había utilizado una paradoja parecida, con la misma estructura hipotética que combinaba humorismo y tristeza, en más de una ocasión: "Nos aliviaríamos si comprendiésemos que morir es la última diversión de la vida" (Gómez de la Serna 1962: 143), "Si no fuésemos mortales no podríamos llorar" (514); "Si la muerte no se pareciese al sueño, la [sic] sería mucho más difícil el sorprendernos" (1141); etc. 
133). No obstante, nos encontramos ante un alejamiento temporáneo porque ya en Trífero (2000) Loriga oscila entre la brevedad de algunos apartados y la amplitud de otros, con párrafos y frases dispares, debidos a su lucha por alcanzar la cuadratura del círculo entre su propensión a cierto énfasis sentencioso y la necesidad de poner a punto un estilo capaz de amoldarse a reflexiones de hondo calado en una narración que, al no descansar por primera vez en un yo que relata los acontecimientos, requiere un enfoque más elaborado. Un cambio de rumbo tan significativo le lleva a ser "más contenido en su lirismo, con una cierta musicalidad clásica y una crítica más fina y humorística" (Manrique Sabogal 2002: II). Estas características se consolidarán en El hombre que inventó Manhattan (2004) (Echevarría 2004: 4), un libro que a causa de su propio planteamiento -se proponía brindar un retrato sesgado y coral de Nueva York (Urioste 2009: 305-306)- pedía un regreso al fragmentarismo, aunque sin perder de vista la unidad de cada uno de los relatos que se deshilachan y se reanudan con el fin de componer el tapiz neoyorquino zurcido por el autor: de ahí que los capítulos se presenten como esquirlas de unos cuentos entreverados entre ellos, urdidos mediante "un estilo lacónico y antirretórico, de frase muy simple" (Sanz Villanueva 2004) que le consiente a Loriga compaginar sus deseos de contar unas historias cautivadoras, y en ocasiones poéticas, evitando incurrir en fogonazos excesivamente líricos, sin por eso tener que renunciar a una visión melancólica y quebrada de la realidad. De tal esmero en pulir su escritura resurgirá cierta propensión a la brevedad, aunque abocada a un tono gris de raigambre centroeuropea, casi walseriana ${ }^{78}$, que alimentará Ya sólo habla de amor (2008), una novela cuya trama impalpable se pierde por los laberintos de la mente de un protagonista empeñado en auscultar su ineptitud en materia de relaciones amorosas. Las divagaciones sobre la grisura de una existencia atemorizada por el amor favorecen una prosa que avanza al compás de saltos y nexos azarosos vinculados al estado anímico del personaje, lo cual favorece la presencia de unos capítulos muy cortos y de varios fragmentos textuales - de nuevo separados por unos espacios en blanco- que abarcan unas pocas líneas o un par de hojas, casi siempre compuestos por unas oraciones mínimas:

A veces bajo la lluvia, se creía capaz de llorar, pero no dejaba rodar una lágrima, pues sabía que no tenía derecho a componer una figura encantadoramente triste. De hecho ya no se permitía ser encantador en ninguna circunstancia. Y sin embargo, se

78. "Es una novela de amor sin amor, de desamor. [...] Diría que está orientada hacia cierta literatura centroeuropea, que incluye a Canetti, a Musil, a Walser, de hecho estos autores forman parte del tema" (Valencia 2008: 23). 
guardaba una pequeña reserva de encanto por si algún día le hiciera falta (Loriga 2008: 16).

Lo que hace Loriga en este pasaje, que constituye un ejemplo de bloque conceptual aislado en la disposición tipográfica del folio, es emplear una técnica aprendida años atrás, cuando su pluma se dejaba guiar por el rock ${ }^{79}$, porque aquí el autor juega con un único concepto -“el encanto”- manejándolo de formas diferentes para que funcione como un estribillo sonoro y semántico que, más allá de los conectores usados, una entre sí las frases. Con toda probabilidad es precisamente esta cadencia narrativa, dictada por una cadena de periodos rotundos, con frecuencia yuxtapuestos, la que lleva a Senabre (2008), en su reseña del volumen, a afirmar que "El estilo narrativo de Loriga recuerda en muchos momentos al de Gómez de la Serna", y, en efecto, el de este último, como subraya López Molina (2008: 133), se fundaba en "la tenuidad, casi inexistencia, de los enlaces extraoracionales y la simplicidad de la sintaxis: predominio de oraciones yuxtapuestas o coordinadas frente a escasez de subordinadas algo complejas", elementos que se repiten en la escritura del primero:

Las conquistas, todas, dependen del paso marcial de la infantería, de los hombres de a pie. De aquellos que caminan y dejan huellas. De los que levantan las banderas. Pero una tropa necesita un arma y una canción y una carta de amor en el bolsillo y Sebastián no tenía nada de eso. Digámoslo ya, Sebastián carecía de una estrategia para la victoria (Loriga 2008: 80).

Senabre (2008), además, pone de relieve otra afinidad entre Ramón y Loriga que estribaría en "la animación de objetos inertes y la cosificación de lo vivo", pero estas técnicas parecen secundarias y necesitan ser matizadas porque, pese a que afloren en Ya sólo habla de amor -"no dejaba de asombrarle la capacidad que tenían algunas personas para sujetar la verdad por el cuello" (Loriga 2008: 37); "Pues llamaba siempre la atención un poco y se diluía al mismo tiempo con la pedantería del mercurio" (43); "La luz en las ventanas de las casas ajenas nos habla siempre de una felicidad que existe fuera de nosotros" $(79)^{80}$; etc.- , le sirven al autor, como es posible apreciar en los ejemplos ofrecidos, sobre todo para captar ideas abstractas o sentimientos, los cuales, en general, sugieren otras metáforas o

79. "Loriga utiliza un recurso frecuente en el rock, coger una idea y jugar con ella, repitiéndola y dándole la vuelta para llegar de nuevo al principio" (Navarro Martínez 2008: 179).

80. Quizás en esta cita es posible oír resonar un eco de la greguería "Sólo la iluminada ventana oval de la buhardilla del palacio parece ser feliz” (Gómez de la Serna 1962: 748). 
símiles $^{81}$ no vinculados a dichas estratagemas que, en cambio, en el caso de Gómez de la Serna, empecinado en regodearse en la faceta oculta de los objetos, resultaban sin duda más espontáneas. Este desvío de lo material hacia una obstinada introspección es una lógica herencia de esa melancólica ironía que contrapunteaba los textos primerizos de Loriga, deudores de una estética rockera marcada por la perentoriedad de los versos de las canciones que, con el paso del tiempo, ha ido deslizándose hacia lo literario, en busca de una depuración que parece proceder de la obra de Marguerite Duras, una figura admirada desde el principio por el autor de Héroes $^{82}$ y que con su escritura entrecortada, descarnada y lírica ${ }^{83}$, representaba un modelo perfecto para alguien tan propenso a la sentencia lapidaria. De hecho, los espacios en blanco, los capítulos breves y la fragmentación de las novelas de Loriga se deben más a la influencia de la escritora francesa que a la de Ramón pero, como hemos visto, al recorrer el trayecto que va de la música a Duras, la voz del autor ha rozado a menudo el tono de la greguería y, sobre todo, la esbeltez del estilo puntillista propio del grafómano madrileño, aunque en el relato Los oficiales -publicado conjuntamente a El destino de Cordelia en 2009- lleve esta tendencia hasta el paroxismo a través de un acendramiento durasiano que, por su vigor, sitúa la prosa de Loriga casi en las antípodas de la exuberancia creativa de Gómez de la Serna:

El humo imagina la chimenea, la chimenea supone la casa, la casa inventa a sus fantasmas. Los sueños traicionan la vida caminando para atrás, hasta el lugar donde no hay nada.

Se camina a crédito, se lucha de prestado, se vence en un sueño, sólo se comparece en la derrota (Loriga 2009: 24).

Sin embargo el deshilacharse del tejido narrativo, tanto en Ramón como en Loriga, podría derivar de un común clima de disolución que permeaba -y permea- las

81. He aquí unas muestras: "Pensó que la belleza de las mujeres se sostenía en la belleza de sus nombres" (Loriga 2008: 66); "No dejaría en ningún caso que un fontanero del alma desatascase sus magníficas cañerías" (103); "como si su vida fuese un calendario con todas las fechas y las horas marcadas de rojo festivo" (162); etc.

82. "En España se hacen juegos malabares para que no se vea nada mientras que, por ejemplo, con Marguerite Duras veo cosas maravillosas. De mayor quiero ser Marguerite Duras” (Martínez 1993: 38).

83. "L'écriture durassienne laisse également entendre un silence des mots, prise dans une dialectique parole/silence, entre un mouvement et une suspension de la parole, où se manifeste una volonté de combler l'absence par une plénitude du langage et le désir d'embrasser la perte dans toute son étendue, dans une écriture du silence et du recueillement. Le silence n'a cesse de hanter l'écriture de Duras. La narration est très souvent hechée, truée de blancs typographiques, de verbes manquants, de phrases nominales, qui laissent place à un silence des mots" (El Maïzi 2009: 155). 
sociedades en las que les tocó vivir, ambas marcadas por una crisis del concepto de colectividad y por un profundo viraje hacia un individualismo extremado que se reflejaría en una atomización de la estructura del texto ${ }^{84}$, una ruptura reivindicadora de una completa autonomía intelectual y una evidente autorreferencialidad ${ }^{85}$ : Gómez de la Serna resumía las características de la nueva literatura de su época enhebrando los adjetivos "individualista, verídica, monista" (Sabugo Abril 1988: 16), mientras que el autor de Lo peor de todo ha expresado su visión del mundo en los siguientes términos: "Se ha sustituido a un millón de personas detrás de una bandera por un millón de personas detrás de un millón de banderas. Se puede ver como el colmo del individualismo y el egoísmo, pero positivamente es el colmo de la libertad personal" (Baños y Rosell 1999: 24).

En efecto, a lo largo del presente ensayo, el destello de la greguería ha sido utilizado siempre como un instrumento subversivo personal para tratar de descoyuntar una realidad histórico-social, o estética, dominante: para Ramón había sido fundamental encontrar una nueva vía literaria que lo liberara tanto de la literatura anterior como de las convenciones sociales y de la tensa atmósfera de su época, y esta doble actitud ha sido recuperada en la contemporaneidad por Prada, Bonilla y Loriga. Para los primeros las técnicas gregueríacas han sido sobre todo un asidero al que aferrarse en su primera fase de formación como escritores, cuando buscaban un estilo que los desmarcara del realismo juvenil en boga entre sus coetáneos, ofreciéndoles al mismo tiempo un prisma para representar el mundo según sus inclinaciones -un humorismo grotesco y venado de pesimismo en Prada y un humorismo burlón y libresco en Bonilla-, mientras que Loriga ha seguido una senda sui generis en la que, al fundir la música rock y la literatura, concebidas como refugios y medios de resistencia al entorno, ha logrado encontrar en la sentenciosidad aforístico-gregueríaca una manera de sublimar y exorcizar sus inquietudes existenciales, a través de una ironía melan-

84. Si inscribimos la producción de Ramón en el Modernismo internacional y la de Loriga en el Posmodernismo, no podemos ignorar que en ambos periodos el artista, alejado de las masas, sólo puede representar el mundo recurriendo a una percepción fragmentaria: "En el Modernismo, la conciencia del sujeto [...] se yergue en el bastión [...] de la posibilidad de la representación. [...] La representación de la realidad abandona el mimetismo maquinal y [...] acaba muchas veces por disolver la realidad en un montón de aprehensiones aisladas” (Ródenas de Moya 1998: 54); “qué ocurre cuando el sujeto que narra percibe no sólo la realidad como fragmentación, sino también su propia subjetividad como caos? Aparece la novela posmoderna" (Lozano Mijares 2007: 155).

85. "La dominante del arte literario del siglo XX es autorreferencial y, por medio de la autorreferencia, acentúa las preocupaciones epistemológicas (sobre todo en el Modernismo) u ontológicas (especialmente en el Posmodernismo) que se detectan en todas las manifestaciones del pensamiento contemporáneo" (Ródenas de Moya 1998: 87). 
cólica extraída de los versos de las canciones y reelaborada mediante una prosa jazzística, recorrida por un aire ramoniano que se vislumbra en la brillantez de las imágenes y en el ritmo en staccato de su escritura.

\section{Bibliografía}

ACÍN, R. (2003). "Dos anotaciones al margen: modernidad y valor de la mirada en Coños de J. M. de Prada" en Juan Manuel de Prada: de héroes y tempestades. (Eds. J. M. López de Abiada y A. López Bernasocchi). Madrid: Verbum.

BAÑOS, A. y ROSELL, O. (1999). “Adiós generación X”. Ajoblanco 118: 17-30. BONILLA, J. 2000 (1994). El que apaga la luz. Valencia: Pre-Textos. BONILLA, J. 2004 (1995). Yo soy, yo eres, yo es. Barcelona: Booket. BONILLA, J. (1996a). El arte del yo-yo. Valencia: Pre-Textos. BONILLA, J. (1996b). Nadie conoce a nadie. Barcelona: Ediciones B.

BONILLA, J. (1996c). "Cada cual por su cuenta. Notas sobre última narrativa en España”. Clarín 1: 7-11.

BONILLA, J. (1998). Cansados de estar muertos. Madrid: Espasa Calpe.

BONILLA, J. (1999). La compañía de los solitarios. Valencia: Pre-Textos.

BONILLA, J. (2001). "Por encima del realismo" < http://www.elmundo.es/ elmundolibro/2001/08/27/anticuario/998907479>. (Acceso 7 agosto 2013).

BONILLA, J. 2003 (2000). La noche del Skylab. Barcelona: Booket.

BONILLA, J. (2008). La plaza del mundo. Valladolid: Universidad de Valladolid. BUERES, E. (1996). “Juan Manuel de Prada tras las huellas de Gálvez”. Clarín 2: 33-37.

CABAÑAS ALAMÁN, R. (2008). "La reescritura de Senos, de Ramón Gómez de la Serna, en La vida invisible de Juan Manuel de Prada” en Ramón Gómez de la Serna y la novela. Nuevas perspectivas. (Ed. E. Navarro Domínguez). Huelva: Universidad de Huelva.

CABRÉ, M. Á. (2000). "La compañía de los solitarios”. Quimera 192: 75-77.

CASTILLO GALLEGO, R. (1999). "Dos aspectos de una novela: Las máscaras del héroe, de Juan Manuel de Prada". Versants. Revue Suisse des Littératures Romanes 36: 153-163.

CATTANEO, S. (2012). La 'cultura X'. Mercato, pop e tradizione. Juan Bonilla, Ray Loriga e Juan Manuel de Prada. Milano: Ledizioni.

CUENCA, L. A. de (1996). "La narrativa de Juan Manuel de Prada". Ínsula 591: 9-11.

ECHEVARRÍA, I. (1993). “Un artista del 'rocanrollo'. El cuaderno de canciones de Ray Loriga”. Babelia 111: 11. 
ECHEVARRÍA, I. (2004). "Melodías de Manhattan". Babelia 636: 4.

EL MAÏZI, M. (2009). Marguerite Duras ou l'écriture du devenir. Berlin: Peter Lang.

FERNÁNDEZ GARCÍA, M. N. (1990). "Superación de la crisis finisecular en la literatura y en el arte: Ramón Gómez de la Serna”. Letras de Deusto 46 (20): 181-190.

FERNÁNDEZ PORTA, E. (1995). “Caídos del cielo”. Lateral 9: 17.

GARCÍA, P. (2003). “Coños o la palabra en estado de ebriedad” en Juan Manuel de Prada: de héroes y tempestades. (Eds. J. M. López de Abiada y A. López Bernasocchi). Madrid: Verbum.

GARCÍA JAMBRINA, L. (2005). "Prehistoria y noticias de un libro de coños” en Coños. (J. M. de Prada). Madrid: Valdemar.

GARCÍA RODRÍGUEZ, J. (2008). "Prólogo. Un mundo, una vasta biblioteca. Del ejercicio (oblicuo) de la autobiografía” en La plaza del mundo. (J. Bonilla). Valladolid: Universidad de Valladolid.

GÓMEZ, M. A. (2001). "Las máscaras del héroe de Juan Manuel de Prada: una reescritura del esperpento". Anales de la Literatura Española Contemporánea 26 (2): 115-132.

GÓMEZ DE LA SERNA, G. (1963). Ramón (Obra y vida). Madrid: Taurus.

GÓMEZ DE LA SERNA, R. (1962). Total de greguerías. Madrid: Aguilar.

GÓMEZ DE LA SERNA, R. (1998). Senos en Obras completas. (Ed. I. Zlotescu). Barcelona: Círculo de Lectores/Galaxia Gutenberg: III: 531-697.

GÓMEZ YEBRA, A. A. (1994). “Introducción” en Greguerías. (Ed. A. A. Gómez Yebra). Madrid: Castalia.

GRACIA, J. (2005). "Una tradición rebelde" en La pluralidad narrativa. Escritores españoles contemporáneos (1984-2004). (Eds. Á. Encinar y K. M. Glenn). Madrid: Biblioteca Nueva.

GULLÓN, G. (1996). “Cómo se lee una novela de la última generación (Apartado X)". Ínsula 589-590: 31-33.

GULLÓN, G. (2003). "Llega a ser quien es: el novelista Juan Manuel de Prada" en Juan Manuel de Prada: de héroes y tempestades. (Eds. J. M. López de Abiada y A. López Bernasocchi). Madrid: Verbum.

JURISTO, J. Á. (1994). "Novelas urbanas, novelillas de urbanización”. El Urogallo 96: 50-53.

LÓPEZ MOLINA, L. (2008). "La greguería en la novela" en Ramón Gómez de la Serna y la novela. Nuevas perspectivas. (Ed. E. Navarro Domínguez). Huelva: Universidad de Huelva.

LORIGA, R. 1999 (1992). Lo peor de todo. Barcelona: Plaza \& Janés.

LORIGA, R. 1998 (1993). Héroes. Barcelona: Plaza \& Janés. 
LORIGA, R. (1994). Días extraños. Madrid: Detursa.

LORIGA, R. (1995). Caídos del cielo. Barcelona: Plaza \& Janés.

LORIGA, R. 2000 (1999). Tokio ya no nos quiere. Barcelona: Plaza \& Janés.

LORIGA, R. 2001 (2000). Trífero. Barcelona: Destino.

LORIGA, R. (2008). Ya sólo habla de amor. Madrid: Alfaguara.

LORIGA, R. (2009). Los oficiales y El destino de Cordelia. Barcelona: El Aleph.

LOZANO MIJARES, M. DEL PILAR (2007). La novela española posmoderna. Madrid: Arco Libros.

LUNA, S. (1998). "Juan Manuel de Prada". Qué leer 24: 120-121.

MANILLA, A. (1997). "Virus contagiosos". Clarín 9: 73.

MANRIQUE SABOGAL, W. (2002). "Ray Loriga: 'Es bueno que el escritor esté desconcertado". Babelia 541: II.

MARTÍNEZ, G. (1993). "Ray Loriga. Un púgil a ritmo de zapping”. Ajoblanco 58: 34-38.

MONTETES MAIRAL, N. (1999): "Juan Manuel de Prada" en Qué he hecho yo para publicar esto (XX escritores jóvenes para el siglo XXI). (Ed. N. Montetes Mairal). Barcelona: DVD.

NAVARRO MARTÍNEZ,E. (2003a). "La nueva novela española a finales del siglo XX" <http://hispanista.com.br/revista/artigo120esp.htm>. (Acceso 28 agosto 2013).

NAVARRO MARTÍNEZ,E. (2003b). "Novelas con banda sonora: la música como recurso técnico en algunas obras de la narrativa española actual" <http://www.um.es/ tonosdigital/znum5/estudios/I-Novelassonora.htm>. (Acceso 28 agosto 2013).

NAVARRO MARTÍNEZ, E. (2008). La novela de la Generación X. Granada: Universidad de Granada.

NÚÑ̃EZ, P. (1998). "Sin el señor Lara cientos de escritores españoles se habrían muerto de hambre". Lateral 37: 34-35.

PEÑA, L. de la (1997). “Las máscaras del héroe. Una novela de excesos”. Reseña 281: 28 .

PRADA, J. M. de 2005 (1995). Coños. Madrid: Valdemar.

PRADA, J. M. de 1997 (1995). El silencio del patinador. Madrid: Valdemar.

PRADA, J. M. de 2008a (1996). Las máscaras del héroe. Barcelona: Seix Barral. PRADA, J. M. de 2006 (1997). La tempestad. Barcelona: Booket.

PRADA, J. M. de (2000). Las esquinas del aire. En busca de Ana María Martínez Sagi. Barcelona: Planeta.

PRADA, J. M. de 2007 (2003). La vida invisible. Barcelona: Booket.

PRADA, J. M. de 2008b (2007). El séptimo velo. Barcelona: Booket. 
PRADA, J. M. de (2008c). "Encoñado" <http://www.elcultural.es/version_papel/ LETRAS/ 22147/Juan_Manuel_de_Prada_Enconado>. (Acceso 31 julio 2013). RÓDENAS DE MOYA, D. (1998). Los espejos del novelista. Modernismo y autorreferencia en la novela vanguardista española. Barcelona: Península.

RÓDENAS DE MOYA, D. (2003). "Ramón en la era del vacío". Quimera 235: 33-37.

RÓDENAS DE MOYA, D. (2008). "Introducción" en Greguerías, relatos, ensayos y otros textos. (Ed. D. Ródenas de Moya). Barcelona: Octaedro.

SABUGO ABRIL, A. (1988). "Ramón o la nueva literatura". Cuadernos Hispanoamericanos 461: 7-27.

SACRISTÁN, M. (1992). “Un mundo quebrado”. El Urogallo 72: 62-64.

SÁNCHEZ MAGRO, A. (1996). "Nadie conoce a nadie. La pérdida del relato". Reseña 274: 34.

SANTANA, C. (2007). "What We Talk About When We Talk About Dirty Realism in Spain" en Generation X Rocks. Contemporary Peninsular Fiction, Film, and Rock Culture (Eds. C. Henseler y R. D. Pope). Nashville: Vanderbilt University Press.

SANZ VILLANUEVA, S. (2004). "El hombre que inventó Manhattan" $<$ http://www. elcultural.es/version_papel/LETRAS/8725/El_hombre_que_ invento_Manhattan>. (Acceso 28 agosto 2013).

SENABRE, R. (1967). "Sobre la técnica de la greguería". Papeles de Son Armadans 134 (45): 121-145.

SENABRE, R. (2008). "Ya solo habla de amor" <http://www.elcultural.es/version_ papel/LETRAS/24170/Ya_solo_habla_de_amor>. (Acceso 3 septiembre 2013).

SERRANO VÁZQUEZ, M. ${ }^{a}$ C. (1991). El humor en las greguerías de Ramón: recursos lingüísticos. Valladolid: Universidad de Valladolid.

STEENMEIJER, M. (2004). "El rock anglosajón en la narrativa postfranquista: Antonio Muñoz Molina y Ray Loriga” en Intermedialidad e hispánica. (Ed. A. Rieger). [Frankfurt am Main]: Peter Lang.

TURPÍN, E. (1999). "Fabular la desilusión”. Quimera 177: 69-71.

URIOSTE, C. de (2009). "Los espacios vividos de Manhattan". Anales de la Literatura Española Contemporánea 34 (1): 305-326.

VALENCIA, R. (2008). "Ray Loriga: 'Le debo mucho a algunos críticos"”. Quimera 296-297: 19-23. 